\title{
A new topographic survey of the walls of Pompeii: Porta Nola from 3D laser scanner to conservation problems
}

\begin{abstract}
Since 2016, within a broad collaboration agreement between the Archaeological Park of Pompeii and the University of Bologna, a new scientific research project started, with the aim to study and document the north-east sector of the walls of Pompeii, included between Porta Vesuvio and Porta Sarno. The first accomplished result was to achieve a new documentation using protocols and procedures inspired by those used by the Plan of Knowledge of the Great Pompeii Project. Within the new research, while complying with the original guidelines, we tried to update some procedures regarding the analysis of the deterioration and to propose new research lines. The works are ongoing thus we present here the first remarks and an illustrative case focused on the context of Porta Nola.
\end{abstract}

\section{From the Plan of Knowledge to the new survey of the walls}

Over the last few years, renewed focus on the conservation of archeological heritage, in agreement with the Guidelines of the Superior Council of Landscape and Cultural Patrimony', has had its most important application in the Great Pompeii Project ${ }^{2}$, through "a programmatic system of organization and carrying out of works for understanding and restoration" 3 . Divided into 6 plans (safety, works, understanding, capacity building, communication, use) the Great Pompeii Project, still ongoing thanks to the renewal of funds until $2020^{4}$, represents an ambitious program of conservation, increased appreciation and research, capable of dealing with various crucial aspects for the understanding and safeguarding of a complex site such as Pompeii, through the activity of both safeguarding and restoration, and management of the hydrogeological risks, up to the use of new pathways and to the definition of

1 Session on December 13, 2010; cfr. Pompei archeologia 2011, 53-66.

2 See http://www.pompeiisites.org/Sezione.jsp?idSezione=357.

3 Fichera et alii 2015, 25-31.

4 See https://napoli.repubblica.it/cronaca/2018/10/09/news/_cosi_il_grande_progetto_ha_rilanciato_pompei_-208592291 
communication and promotion systems $s^{5}$. At its heart, the Plan of Knowledge, now finished, represented a sort of 'protocol' not only for the analysis of the conservation state, but also in terms of the complete and homogeneous documentation of the Vesuvius site and a systematic organization of the data ${ }^{6}$. In the words of its scientific director, Massimo Osanna, we can say that 'The Plan for Knowledge is closely linked to a new computer system, a Web-GIS created thanks to the Great Pompeii Project, into which all of the data related to the monitoring and conservation of the site are put, but also scientific and archival data, both from the past and of the future"'.

The foundation of the Information System is the data gathered and stored by different specialists (archeologists, topographers, structural engineers, architects and restorers), thanks to clearly defined and standardized technical specifics, with the aim of documenting the physical state of the archeological remains of Pompeii.

In order to get this result, there were three different lines of work: the first step was the planimetric and altimetric survey of all of the conserved structures. This consists of planimetry and horizontal sections in 1:50 scale created by dividing up each individual building from its doorstep using the building techniques implemented. To these sections, some vertical sections along the main incline lines were added along with some street front perspectives. For the first time the site of Pompeii was given a survey fit for analysis, the study of the structures and the evaluation of their deterioration ${ }^{8}$. In the most important cases, the buildings were surveyed using a laser scanner, in order to get a highly detailed three dimensional survey.

The second line of work was a photographic and photogrammetry survey of every single vertical and horizontal surface (walls, floors and covers, furniture). The photos obtained using a full frame camera, and tilted and decentered lenses, were taken with metric references, color-metrics according to a precise anagraphic definition'. The photographs attained were calibrated to make the exposure and colors homogeneous, in order to make the outcome optimal for reading the surfaces. These images were then processed with photogrammetry techniques to orthorectify them, thus obtaining the graphic basis for the analysis results on the conservation state and the mapping of deterioration and for a structural analysis.

5 Please see Osanna-Nistri 2014; Osanna 2017, 5-7 and more recently Osanna 2018a; Osanna 2018b.

6 Giorgi 2017, 15-19.

7 Osanna 2017, 5-7.

8 Until now a survey was available with a 1:500 scale of the inner urban area and therefore 10 times less detailed, the result of a combination of surveys done with different techniques.

9 Two photos were taken of every vertical and horizontal surface. The first photo was taken with the insertion of a reference panel for the calibration of colors (colorchecker), a meter stick, a reference to geographic North, and a slate blackboard indicating the anagraphic code of the photographed surface. The code was made up of the indication of the site (Pompeii), regio, insula, civic, room, surface according to the four cardinal points, e.g. P IX $1444 \mathrm{~N}$. The second photo was taken without references. 
The end results following these standards were then the documentary basis for the third line of work, the real heart of this project, the documentation and mapping of the conservation state of every single vertical (walls) and horizontal (floors) surface and structural wall furnishings (benches, impluvia, baths, stairs, etc). The information gathered in the field by a team of multidisciplinary specialists made up of architects, structural engineers, restorers and archeologists was gathered in the field and recorded in line with the regulation UNI 11182/2006.

The entire body of elaborated data was run into a dedicated database, a GIS/ WEBGIS to manage, consult and investigate the information.

Even so, the Plan of Knowledge did not include the walls, which are in any case the object of study and documentation projects, for example that of the University of Rome Tor Vergata in the northern section ${ }^{10}$. Nevertheless, large sections of the ancient city walls were still waiting to be analyzed and documented according to new standards. This pushed the Department of History, Cultures and Civilizations (DiSCi) of the University of Bologna to activate a research convention for the study and documentation of the section of the walls to the north-east of Pompeii, between Porta Vesuvio and Porta Sarno.

The first aim of this new research project, still ongoing, was to document this area using the standards inspired by those used in the Plan of Knowledge". In this new project, even keeping the original protocol unchanged, we nevertheless tried to update some procedures in light of the experience gained in the field, for example, regarding the analysis of the deterioration. Furthermore, new lines of inquiry were added that were not part of the Plan of Knowledge, such as the study of the structures using the typical methods of architectural archeology, also with the aim of scheduling eventual stratigraphic surveys. As this project is still going on, we thought to present here a first exemplary case focusing on the context of Porta Nola ${ }^{12}$.

\section{Porta Nola: history of studies}

The current state of knowledge on Porta Nola, the veru urublanu ("gate of the urbs") of a noted Oscan inscription of the series eituns ${ }^{13}$, is mainly due to the exca-

$10 \quad$ Fabbri 2015

11 In 2015 DiSCi has in fact participated in the Plan of Knowledge as an economic worker of Lot 3.

12 The present contribution is mainly taken from the thesis work for her specialization in Architecture of Ms. Silvia Bergami. "Le mura urbiche di Pompei antica. Proposta di un metodo per la mappatura del rischio attraverso l'analisi dello stato di conservazione e della vulnerabilitä" thesis of Specialization in Architectonic and Landscape Heritage, University of Studies in Florence, speaker Maurizio de Vita, co-speakers Enrico Giorgi, Michele Silani.

13 Vetter 1953, n. 28. 
vations carried out in the 1930s by Amedeo Maiuri. As the illustrious archeologist states, the explorative digs in 1929 alongside the embankment between the walls and in front of the external curtain walls "allowed for a planimetry to be revealed that not only rectifies and completes Mazois's antique one, but presents also a clear vision of the various wall structures" ${ }^{\prime \prime}$. Known of since 1812, in fact, thanks to the descriptions and planimetry of Mazois, Porta Nola is remembered also by Nissen in 1877, who reported the theft of some blocks of the upper part of the wall, and by Overbeck in $1884^{15}$. The excavation of the gate, which "brought to light the external front and the extension of Via Nolana outside the walls up to the sepulchral monuments that lined $i t^{\prime \prime}$, was completed in 1907-1908 ${ }^{17}$.

The building sequence of Porta Nola is linked to the recognition of the construction phases of the entire circle of city walls that, traditionally in studies, is mostly based on the reconstruction suggested by Maiuri, updated thanks to the investigations done in the mid-1980s between Porta Nocera and Tower IV, between Porta Nola and Tower VIII, near the so-called Porta Capua (1993 and 2005), and again in Porta Nocera ${ }^{18}$.

Up to now, 6 construction phases have been identified that can be categorized as follows:

- Phase 1 Archaic: Sections of wall in blocks of "pappamonte" (local grey tuff) and soft lava ${ }^{19}$ (6th century BC);

- Phase 2 'orthostatic': wall sections with double curtain walls in limestone blocks and "emplecton" in stone shavings and dirt (end of 6th-beginning of 5th century $\mathrm{BC})$;

- Phase 3 "paleo-Samnite": curtain wall visible on the entire perimeter of the plateau of Pompeii in opus quadratum blocks of Sarno limestone with an embankment (end of the 4th - 3rd century BC);

- Phase 4 "meso-Samnite": second more internal curtain wall in opus quadratum blocks of tuff, extension of the upper part of the previous curtain wall and widening of the agger system (second Punic war).

14 Maiuri 1930, 206.

15 Mazois 1812-1824; Mazois 1824; Mazois 1829; Mazois 1838; Nissen 1877, 484 e sg.; Overbeck-Mau 1884.

16 Maiuri 1930, 206.

17 Spano 1910, 385 e sg.

18 Maiuri 1930, 218-219; De Caro 1985, 75-114; Chiaramonte Trerè 1986; Etani 2010; Gasparini, Uroz Saéz 2012, 9-67.

19 There are various contributions dedicated to the petrographic study of building materials of the structures of Pompeii. Among these, see Kastenmeier et alii 2010, 39-58. For a brief overview of the building techniques, see Guidolbaldi, Pesando 2016, 2-7. 
- Phase 5 "late-Samnite": resurfacing in opus incertum of several sections of the outer wall curtain and insertion of the 12 towers resurfaced in plaster imitating the orthostatic ones (last decades of the 2 nd century BC);

- Phase 6 "of the Roman colony": restoration in various techniques of several sections of the walls and of some gates after the damage due to the attack on the city by Silla in the bellum Italicum (after 89 BC) ${ }^{20}$.

Recent research, currently ongoing in the northern section ${ }^{21}$, has led to some doubts about the sequence of building phases of the walls of Pompeii described herein, in particular regarding phases 3 and 4 and the distinction between two systems with a single curtain wall and embankment one after the other ${ }^{22}$. While awaiting the publication of the results of these new excavations, it is worth underlining how one of the main distinctive criteria put forth by Maiuri to identify the two phases paleo and meso-Samnite, that is to say the use of different building

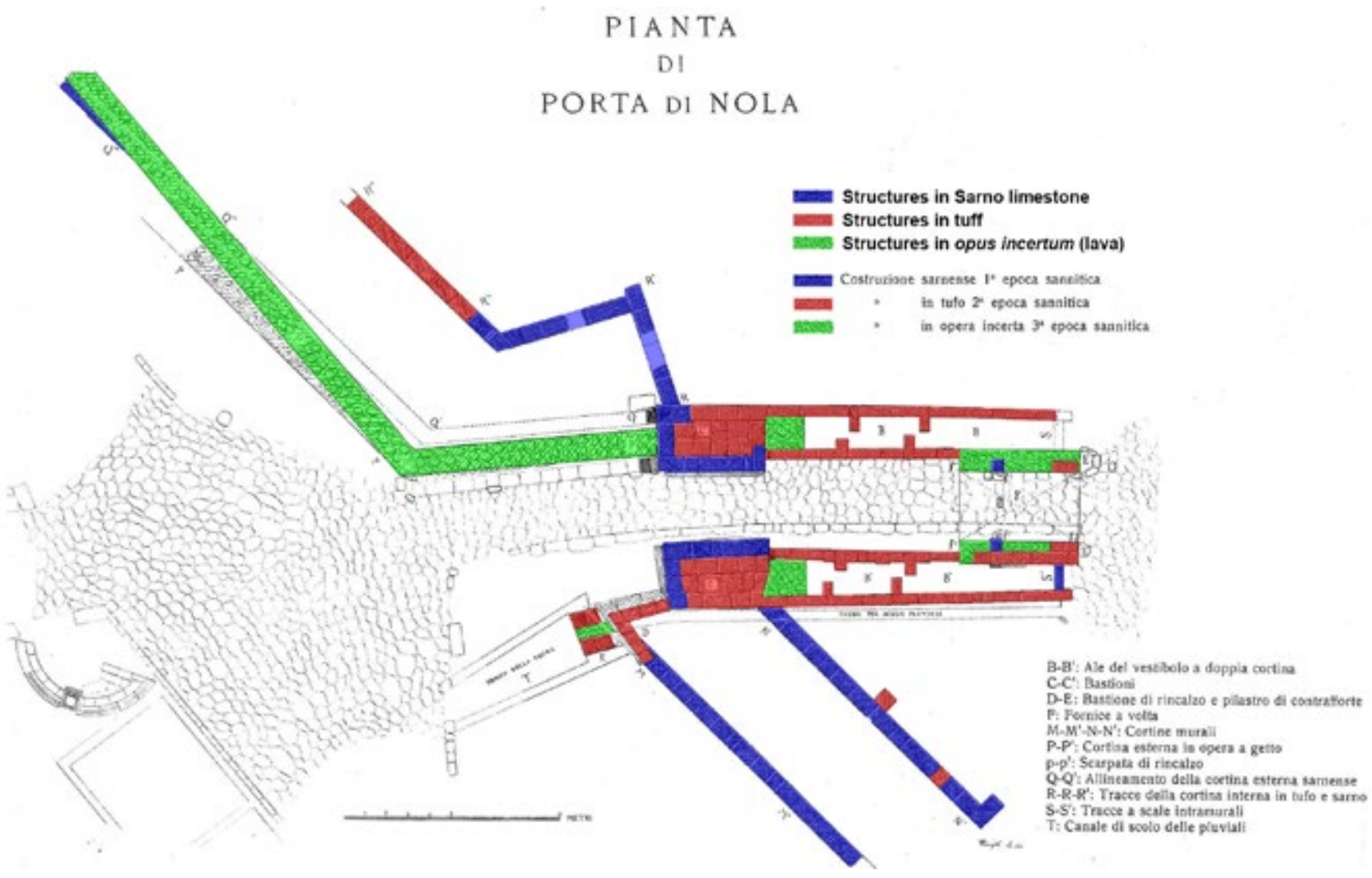

20 An inscription mentions the restoration carried out by the duoviri of the colony Cuspius and Marcus Loreius, CIL X, 937.

21 Regarding this, see Mandolesi 2017, 12-14.

22 Fabbri 2015, 29-47; Anniboletti 2015, 49-70. 
materials (Sarno limestone and tuff), does not represent a rule of thumb and the situation is much more varied with a mixed use of materials in both curtain walls ${ }^{23}$.

Also regarding the area of Porta Nola, the current identification of the construction phases is mostly taken from Maiuri and is based in part on his canonic distinction of building materials (Fig. 1).

The first structure of the gate was dated to the first phase "paleo-Samnite" (end of the 4th century BC). Even if it was built earlier and even if it mostly uses tuff in the inner structure of the external bastions and there is a certain lack of organicity in some elements (corner bastion D), this structure has been compared to Porta Stabia. Porta Nola, in particular, is characterized by two external bastions in opus quadratum limestone blocks (B and B' according to the names of Maiuri) and filled in with a structure made of tuff blocks. These bastions join up on the edge of the plateau and the gate at different angles, so that the eastern side seems further out and taller than the western one, making it appear to be a 'reversed Porta Scea'.

In the second phase, "meso-Samnite", the gate was reinforced, thanks to the private evergetism of meddix tuticus V. Popidius remembered in an inscription found nearby (Vetter 14). The wall facings in limestone were substituted with blocks of tuff which outlined the uncovered atrium (aulè) and maybe a barrel vault was built also in tuff ashlars. The long double-curtained wings, totally tiled and with embankments to contain the agger, were accessible by way of stairs on the sides of the gate built between the two inner curtain walls, just as in Porta Stabia.

In the "late-Samnite" phase (end of the 2nd century BC), the south-eastern bastion was rebuilt in lava using opus incertum, moving forward with regards to the previous external curtain wall. Also the gate was rebuilt in Roman cement and decorated with ornamental elements, such as the head Minerva present on the keystone of the inner vault. Lastly, a water drainage system was built that passed through the embankment on the western side of the gate, with a banked canal which functioned as a sewage drain and that still today comes out at a pilar made of Sarno limestone blocks ${ }^{24}$.

\section{For a new documentation: the laser scanner survey and analysis of the buildings}

Given that the need to produce a documentation in line with the standards of the Plan of Knowledge was pinpointed as the main goal of our project, it was immediately decided that a survey and documentation method would be used that allowed

23 Anniboletti 2015, 62. Also regarding the quarry marks, similar symbols are present both on the limestone and the tuff blocks, see Bochicchio 2015, 45-47.

24 Maiuri 1930, 210-211, 215-217; Anniboletti 2015, 57, 66-67. 
for an ulterior upgrade, as well as obtaining the requested products without precluding the possibility to acquire data for more complex elaborations.

It is for this reason that for the topographic and archeological survey the choice fell on the use of a laser scanner. More specifically, for the survey of the walls, a $T o F$ Leica P30 laser scanner was used, with hybrid WDF technology ${ }^{25}$, and dual-axis compensation ${ }^{26}$ active for the entire range of scanning. Along the wall section, 171 scans were taken, in autoresection mode with two targets (4 parameters) for the determination of the station point ${ }^{27}$, with a scan rate of $6 \mathrm{~mm}$ every 10 meters $^{28}$. As for the radiometric profile for the colorization and texturization of the point clouds, the images were taken with the internal camera ${ }^{29}$.

The recording of the point clouds was done using the software Leica Cyclone. The groups of scans taken in the field in autoresection mode were recalculated based on the targets and were aligned and recorded based on common scans, in cloud to cloud mode ${ }^{30}$, with the application of the ICP (Iterative Closest Point) filter ${ }^{31}$. The maximum error in the cloud to cloud recording was of $0.009 \mathrm{~m}$, in line with the precision of this instrument.

The geo-referencing of the survey was done with forced centering of the targets based on the topographic network of the Archeological Park of Pompeii. The monographs of the datum points, materialized on land with topographic markers, were provided by the Park itself.

The cartographic referencing system used was the national system Gauss-Boaga Fuso Est Roma 1940 (EPSG 3004). Also the residual error in the measurement of the vertices used for the geo-referencing did not go over $0.007 \mathrm{~m}$.

The overall cloud of the laser scanner survey was lastly filtered, cleaned of eventual disturbances (noise) such as vegetation, and optimized in its radiometry (elimination of points subject to elevated or low exposure), working on both the individual scans and on the completed cloud.

25 https://w3.leica-geosystems.com/downloads123/zz/tps/nova_ms50/white-tech-paper/Leica_Nova_MS50_WFD-Wave_Form_Digitizer_Technology_TPA_en.pdf

26 http://www.leica-geosystems.co.kr/downloads123/hds/hds/general/white-tech-paper/Leica_ScanStation_tilt_compensation_wp_en.pdf

27 https://surveyequipment.com/assets/index/download/id/735/

28 Sgrenzaroli, Vassena 2007, 20, par. 4.

29 The Leica P30 laser scanner is one of the best on the market in terms of the final spherical image resolution, with a resolution of 700 megapixels, and at the same time it has the option to use the HDR system with 3 step acquisition for every photo taken. https://www.lnrglobalcom. $\mathrm{nl} /$ images/brochures/leica-scanstation-p-series-hdr-wp-en.pdf

30 Jacobs 2005, 30-37.

31 Besl, MacKay 1992, 239-256; Sgrenzaroli, Vassena 2007, 48. 

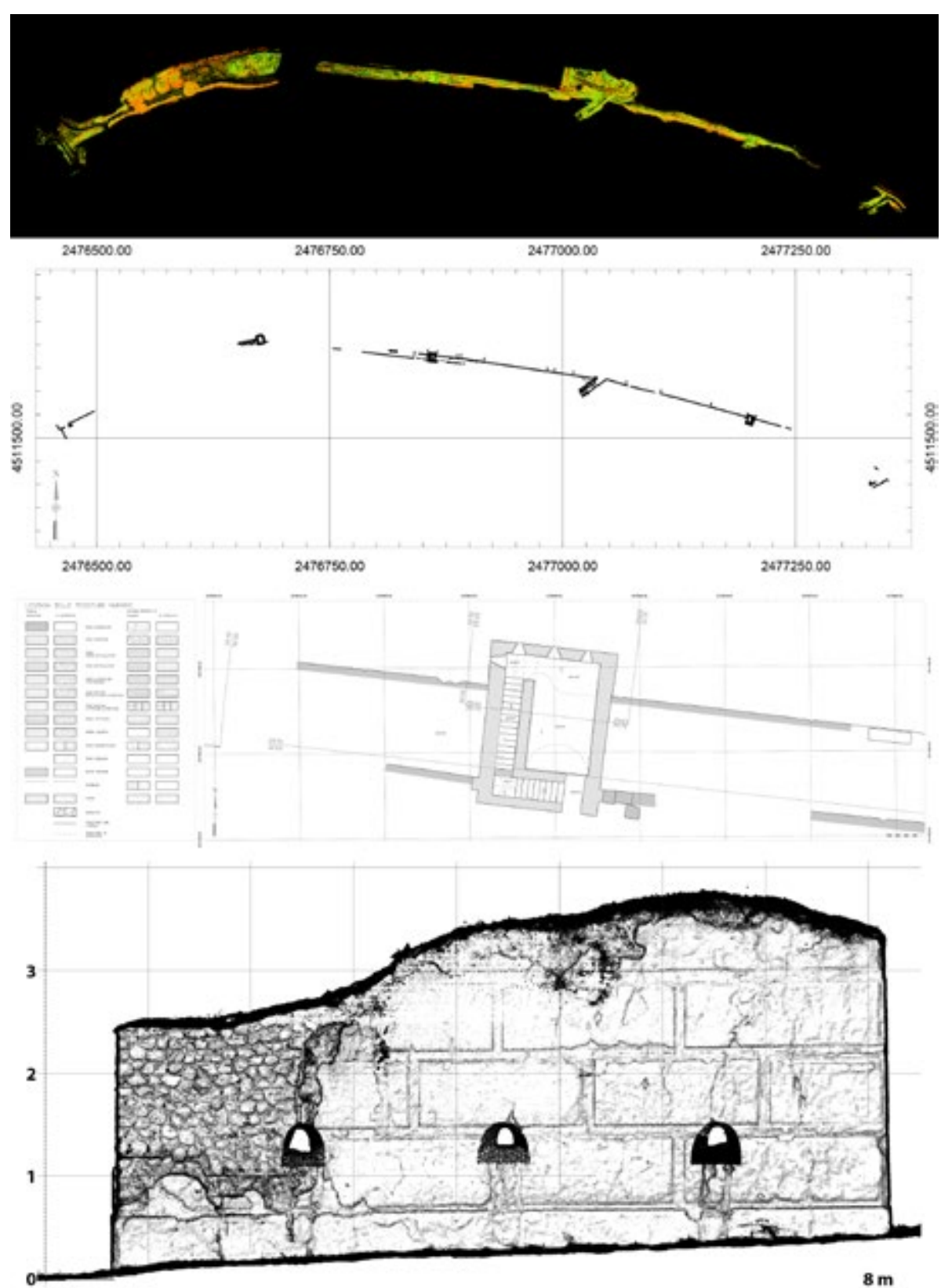

Fig. 2. General planimetry from Porta Vesuvio to Porta Sar no and perspective drawing near Tower VIII derived from the laser scanner

- Site: P. indicates the site of Pompeii; in continuation of the urban regiones;
Lastly, the extraction of a planimetry was done in a scale of 1:50 of the entire section of walls (Fig. 2) and of the wall prospects of the towers (VII, VIII, IX), and of the gates (Porta Vesuvio, Porta Nola, Porta Sarno) (Fig. 2), characterized according to the graphic specifications of the Plan of Knowledge.

In the absence of an anagraphic definition of every single vertical and horizontal surface, a fundamental tool for unequivocally identifying elements of both the archeological documentation and of the mapping of deterioration, an anagraphic reference system was defined in line with the system used during the Plan of Knowledge. More specifically, in the absence of blocks and housing we tried to make the coding homogeneous starting with the section of wall to be documented and with the main structural elements (gates and towers) as follows (Fig. 3):

- Regio: X. Regio X, is used as a conventional way of indicating the ring of walls 


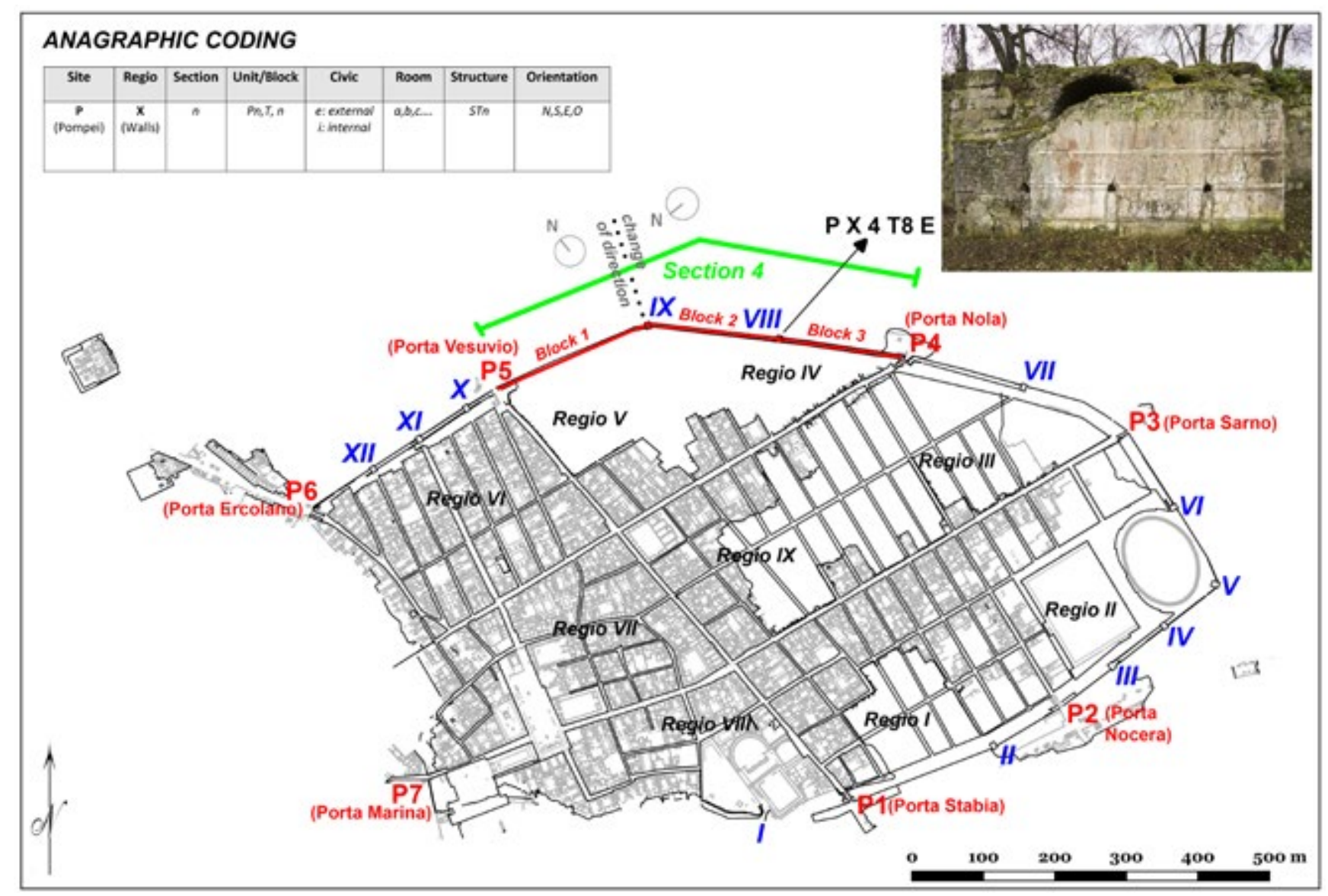

- Section: "Section" refers to a section of wall that goes from one gate to the next ${ }^{32}$

- Unit/Block: this term refers to an uninterrupted Section, the Towers and the to codify every single vertical and horizonGates $^{33}$;

- Civic: this term indicates the internal "i" or the external "e" curtain wall;

- Room: with the Towers or the Gates, when it is possible to identify an enclosed room, this area is indicated with a lowercase cursive letter $(a, b, c .$.$) ;$

- Structure: defined as "structures" and indicated with the abbreviation "ST" are the independent structural elements (stairs, columns, etc.) and they are ascribed to the main structures (Towers, Gates, curtain walls);

32 More specifically we established: section 1 from Porta Stabia (included) to Porta Nocera, section 2 from Porta Nocera (included) to Porta Sarno, section 3 from Porta Sarno (included) to Porta Nola, section 4 from Porta Nola (included) to Porta Vesuvio, section 5 from Porta Vesuvio (included) to Porta Ercolano, section 6 from Porta Ercolano (included) to Porta Marina, section 7 from Porta Marina (included) to Porta Stabia.

33 The numbering was done clockwise and at each interruption the reference number was increased. 
Fig. 4. Photographic and photometric documentation: calibration and orthorectified images

Fig. 5. GIS databank: codification of the structures and

georeferencing of the previous archeological investigations
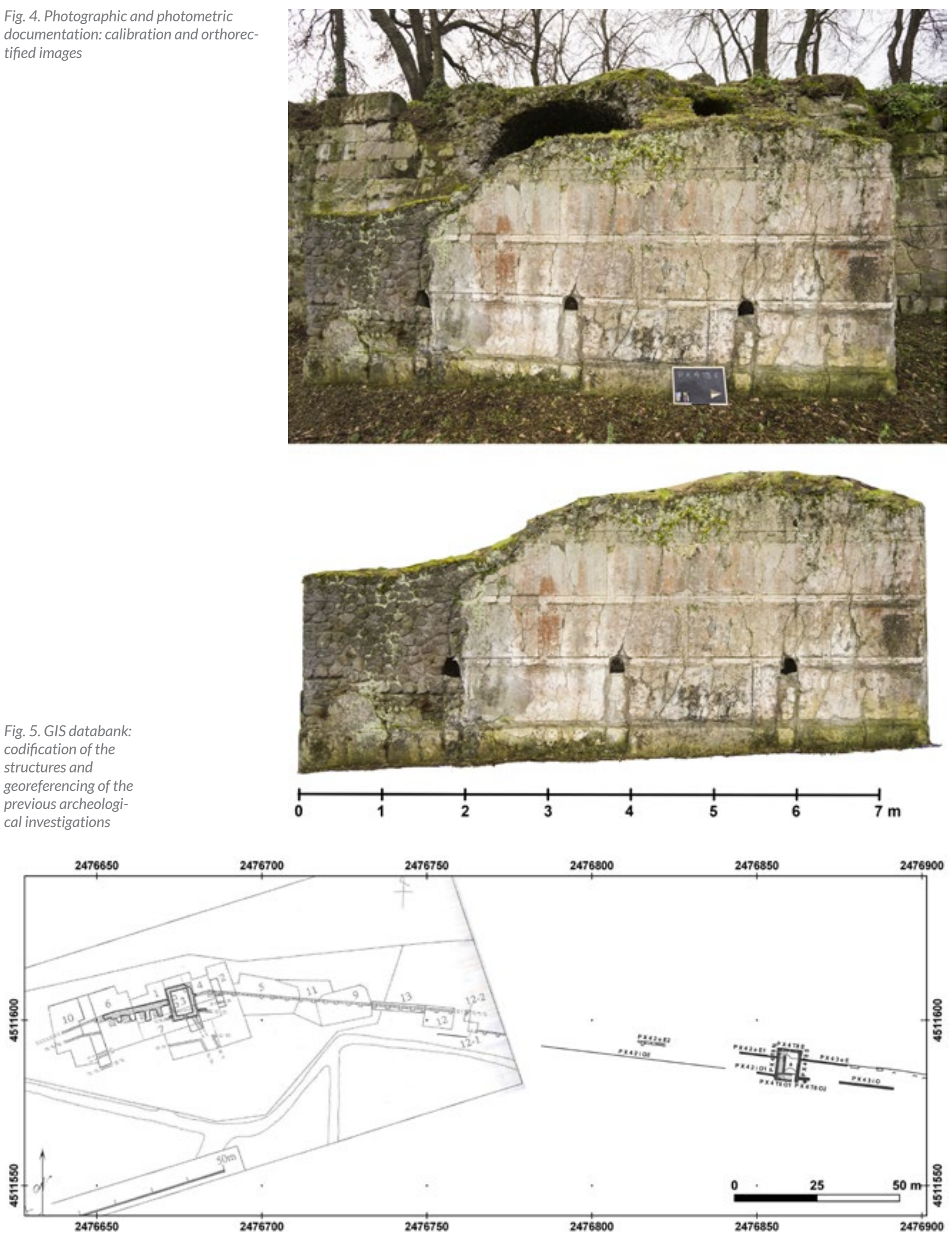

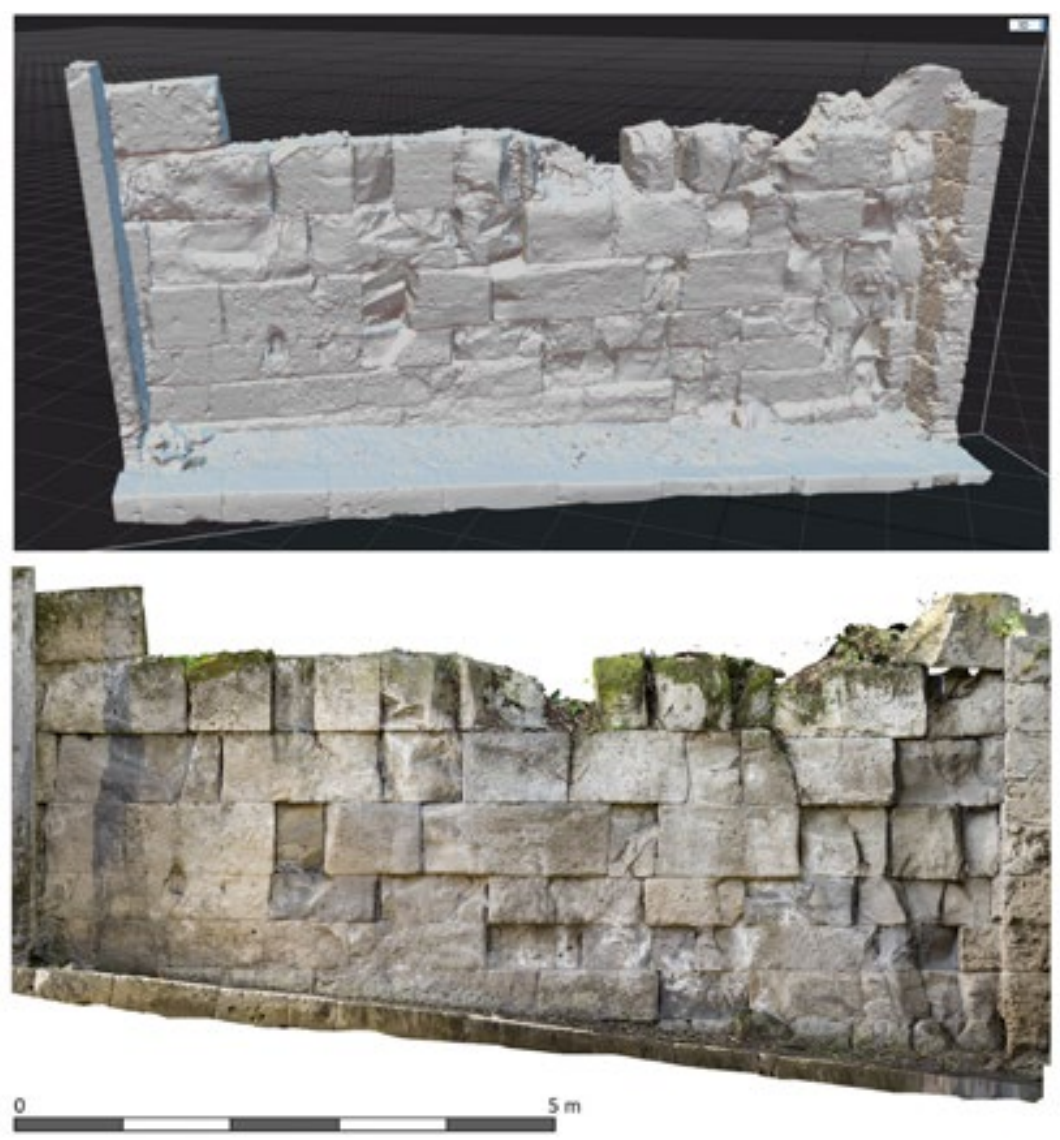

Fig. 6. Three-dimensional model of the surfaces (Digital Surface Model) and their relative orthophoto

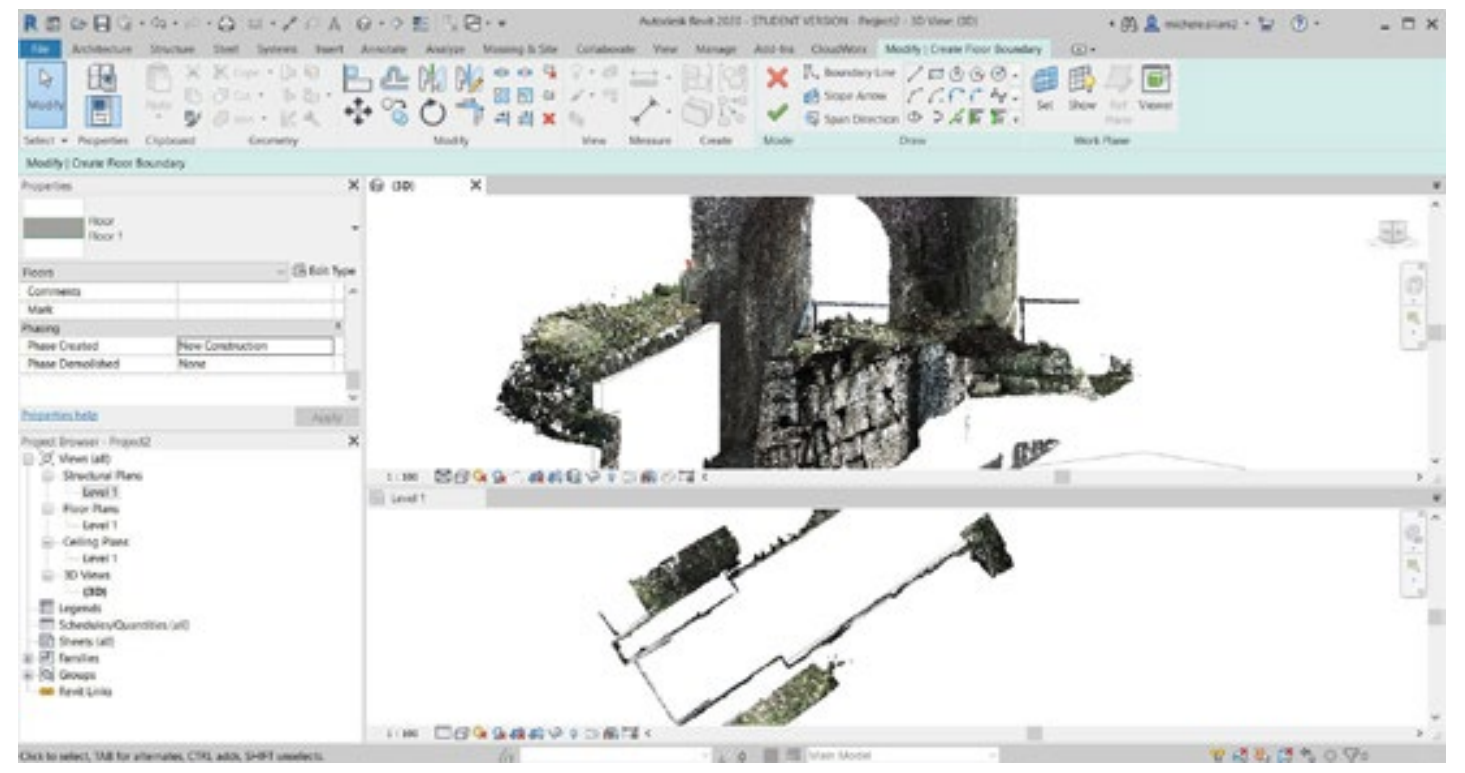

Fig 7. BIM (Building Information Model) being created 


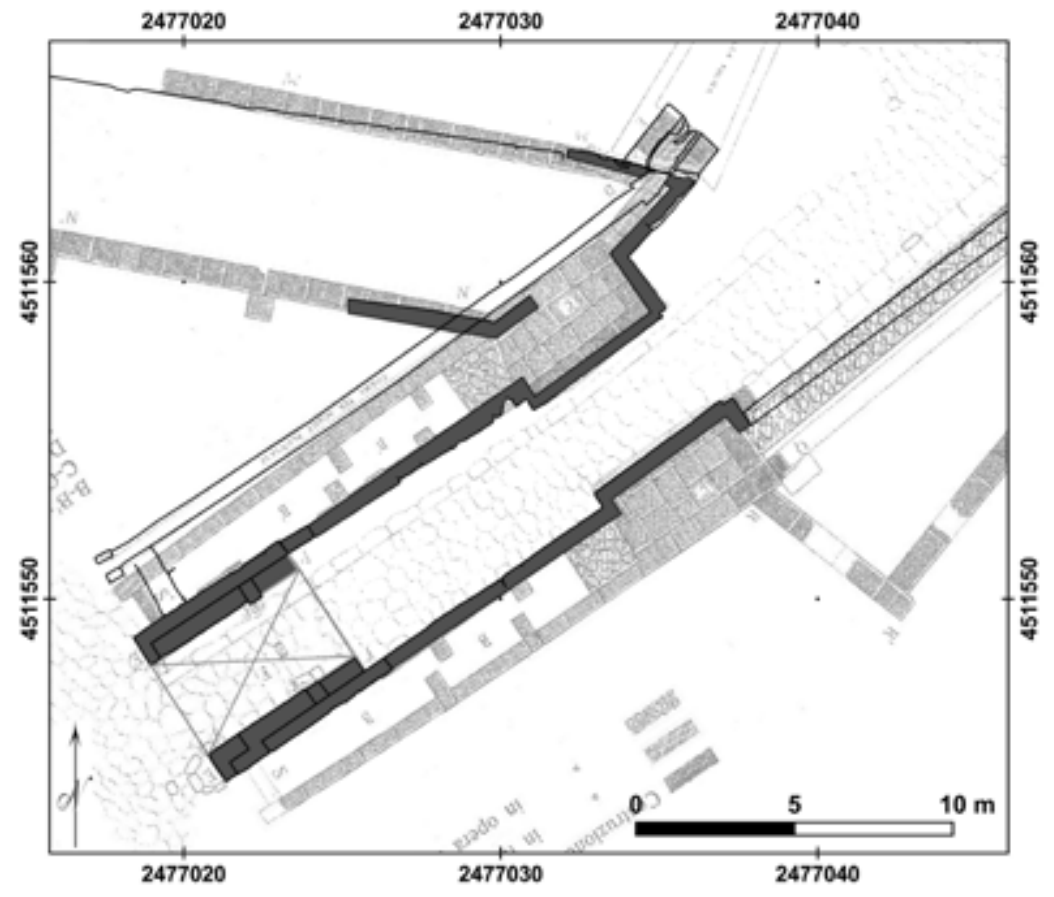

Fig. 8. Superimposing of the new planimetry with the documentation published by Maiuri following the digs in 1929
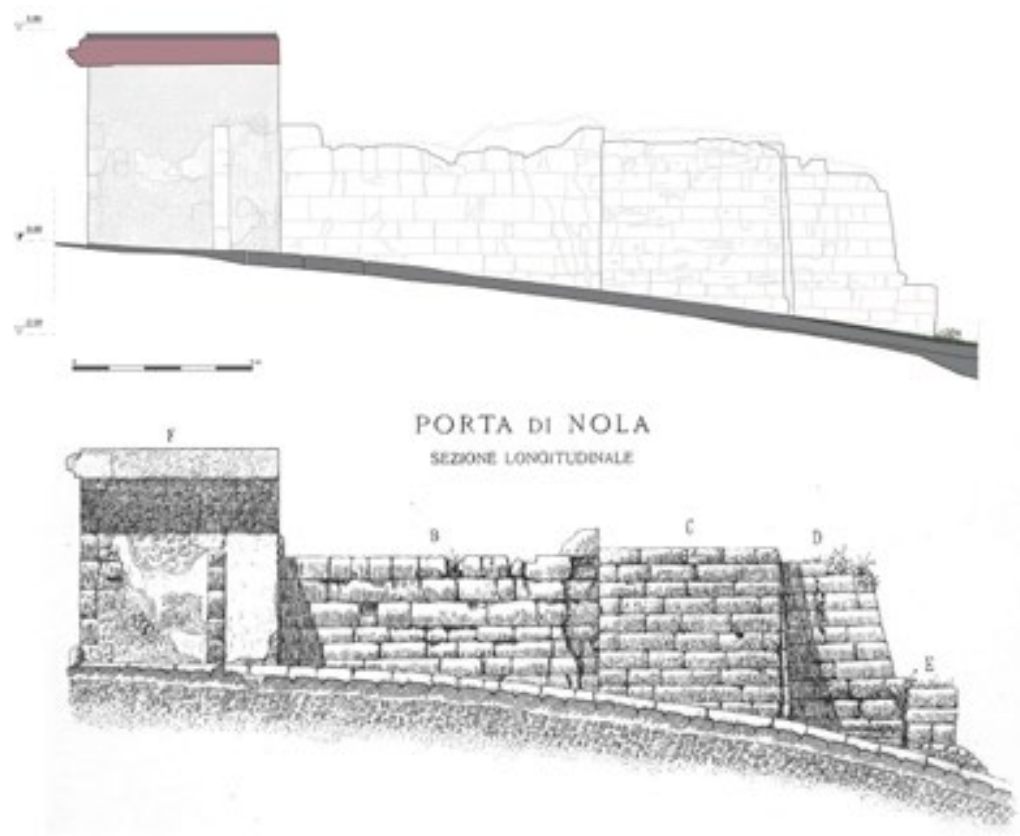

Fig. 9. Porta Nola, perspective drawing north of the atrium. Comparison between the new survey and that of the 1930s (Maiuri 1930, Tav. XI)
- Orientation: this refers to the orientation of the vertical surfaces (walls) defined using the Cardinal points North, South, East, West ${ }^{34}$. The letters "C" and "P" indicated respectively the wall coverings and the horizontal surfaces (pavements or floorings).

The anagraphic coding represents the reference basis also for the photographic and photometric documentation. All of the surfaces identified were in fact photographed with a full frame Sony Alpha 7r camera and a $16 \mathrm{~mm}$ autofocus lens. The images including the anagraphic coding, colormetric and metric references, were then calibrated and underwent a process of orthorectification (Fig. 4).

All of the materials have been momentarily inserted into a GIS database built using the same specifications as the platform of the Plan of Knowledge, while waiting to put the data inside the latter database (Fig. 5).

At the same time, the innate potential of the laser scanner survey was taken advantage of to create three dimensional models through the process of modeling the surfaces (mesh) and for the extraction of orthophotos (Fig. 6). The last aim, which is being carried out now, is the creation of a single three dimensional database which can recognize the informational systems already being used and

34 In the case of the north-eastern section of the wall of Pompeii from Porta Vesuvio to Porta Sarno a change in orientation was noticed at the level of Tower IX. 
enhance the organization of data and the state of understanding starting from the third/fourth dimension ${ }^{35}$ (Fig. 7).

The new survey of the structures was lastly compared to the most complete documentation produced up to now, that is to say the planimetry published by Maiuri after the excavations in $1929^{36}$ (Fig. 8).

The result highlighted the fact that the planimetry of Maiuri remains even today the major source of information in our possession for the study of Porta Nola, both for its metric precision and for the visibility of the structures.

Also the comparison of perspectives of the atrium demonstrated the quality of the 1930s survey and its highly informative nature regarding the analysis of buildings, also in terms of studying the deterioration (v. infra) (Fig. 9).

Until now, the analysis of the above ground remains has confirmed what was seen by the illustrious archeologist. The two external wall coverings of the wings of the atrium in tuff blocks (B and B') rest on bastions in Sarno limestone blocks (C and

Fig. 10. Porta Nola: new elaboration of the planimetry by Maiuri 1930 (Tav. X) and illustration of the relationships between the main building elements

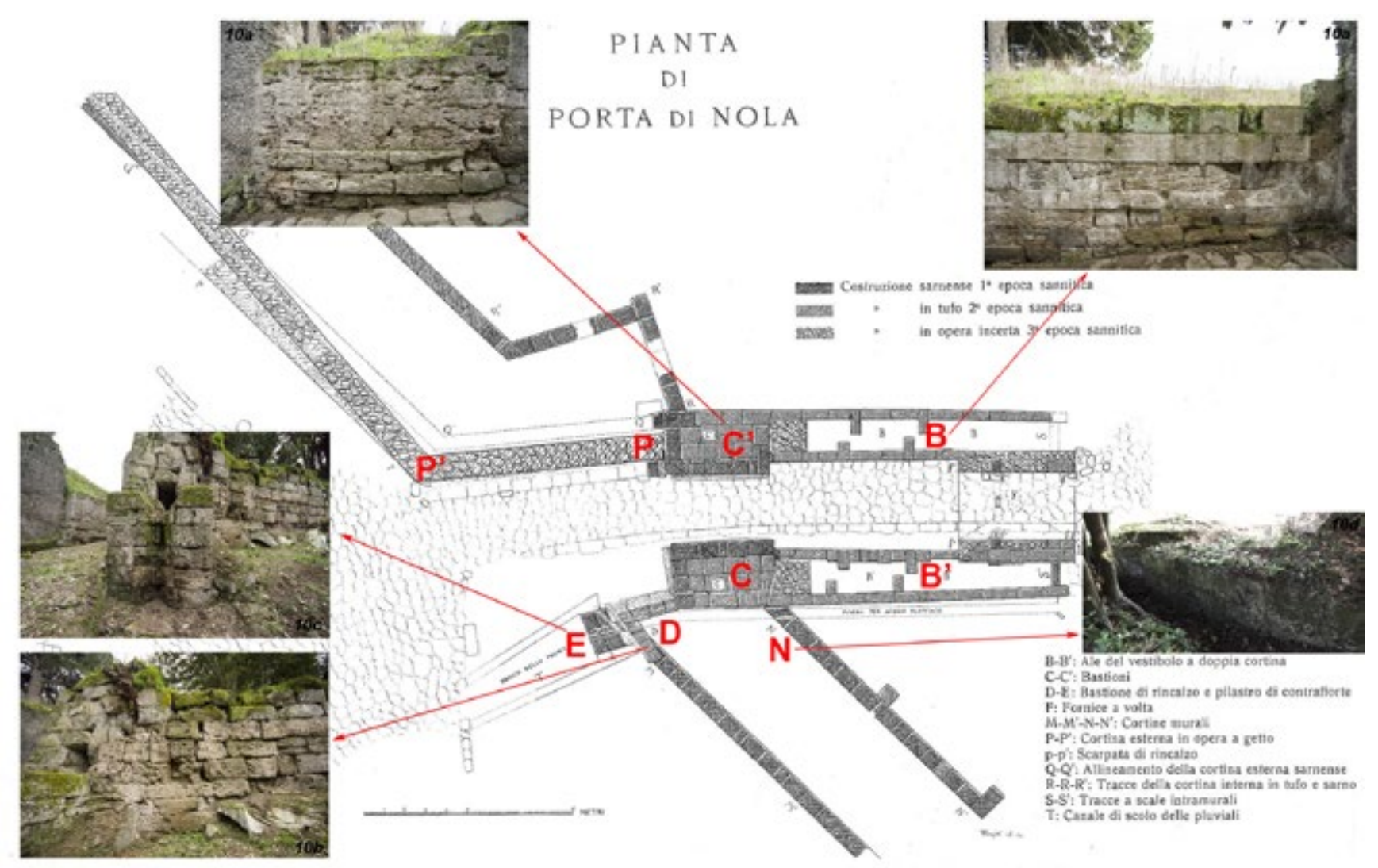

35 Regarding this, the organization of data will be managed not only with CAD/GIS but also with BIM (Building Information Model). For the most recent applications of BIM in archeology see Kainua 2017.

36 Maiuri 1930, tavv. X-XI. 
C') that stick up in some points (Fig. 10a). The internal wall coverings are no longer visible on the wings and the nucleus of the bastions. The reinforcement bastion (D), made with Sarno limestone blocks in the lower part and tuff blocks in the upper part, appears to be resting on bastion C, allowing it to join with the external curtain wall (Fig. 10b). At the same time, the pillar (E), which allows for the drainage pipe coming from the northern side of the gate to reach the outside, interpreted as being in support of the bastions $\mathrm{C}$ and $\mathrm{D}$, is evidently leaning on the latter (Fig. 10c). The relationship between the innermost curtain $(\mathrm{N})$ in Sarno limestone blocks and the bastion (C) is partly visible, where the first supports the second (Fig. 10d). Lastly, also evident is the later building of the southern bastion in opus incertum (P-P') supporting the bastion in limestone blocks $\left(\mathrm{C}^{\prime}\right)$ and of the walls in opus incertum of the gate which reinforce the original abutments in opus quadratum blocks and which rest on the wings of the atrium in tuff blocks ( $\mathrm{B}$ and $\left.\mathrm{B}^{\prime}\right)$.

Nevertheless the doubt remains regarding the validity of the subdivision in the two Samnite phases characterized by the presence of different building materials. If the recent line of research advanced of a possible single building moment characterized by a structure with a double curtain wall is valid for the rest of the wall circuit $^{37}$, then also the context of Porta Nola could have been planned out singularly with a gate in opus quadratum blocks for defense purposes with two wings and two more advanced bastions, following the slope of the plateau. In a second moment the consolidation works done in opus incertum would have been necessary. These considerations at the moment are possible to put forth thanks to the new surveys and the new documentation, and it is evident that only future stratigraphic investigations will be able to resolve this conundrum.

\section{The mapping of deterioration and the evaluation of the conservation status}

The analysis of the state of conservation of the section of wall of the north-eastern area of Pompeii, located between Porta Vesuvio and Porta Sarno, is based on the proposed methodology used during the Plan of Knowledge of the Great Pompeii Project ${ }^{38}$ for the mapping of the archeological site. With the analysis of the walls, and in particular of Porta Nola, a few variations in the application of this method have been proposed in order to overcome some difficulties in carrying it out due to a different type of construction compared to the types present in the insulae.

37 Fabbri 2015, 41-43.

38 Fichera, Malnati, Mancinelli, 2015. 
The mapping of the forms of deterioration of the walls was taken on with a direct method, through visual observation $\mathrm{s}^{39}$ and the documentation of phenomena on site. This qualitative approach ensures a rapid reading and mapping of the phenomena, guaranteeing immediate results on the conservation status of this patrimony.

The evaluation of the state of conservation of an archeological artifact is an iterative procedure that links the survey phase and study of the sources to the analysis of the environment $t^{40}$, of the materials and of the building techniques.

These latter factors play a fundamental role in the activation and in the development of forms of deterioration and in their evolution, influenced also by the orientation of the surfaces, by winds and by the exposure to irradiation. These phenomena act simultaneously and in every direction. Furthermore, only mapping the architectonic surfaces does not provide sufficient data for a complete evaluation of the conservation status of the artifact.

The wall circuit of Pompeii is characterized by a type of very porous material, more specifically Sarno limestone and ignimbrite campana ${ }^{41}$, which winds around for about 66 hectares of surface.

The dimension of the wall work analyzed requires an evaluation of the phenomena on wide surfaces characterized almost totally by a haphazardness, a simultaneousness of forms of alteration in the stone material. In fact, the phenomena of alveolarization, disintegration, presence of biological colonization and vegetation, erosion and efflorescence are diffuse, which co-exist and influence each other.

This qualitative approach to the mapping of phenomena allows us to pinpoint, only for comparison, an inferior limit, a "background noise", under which the form of alteration is not considered significant ${ }^{42}$. The concept becomes clear if, for example, we compare the effect that lichens produce on a painted surface compa-

39 "It is, however, a known fact among experts of this sector that, of ten, a well conducted visual observation of a building object can already provide immediate answers to very simple and easily recognizable problems, allowing for the selection of more complex ones (which in many cases can be taken on with simple survey construction tools) and to establish, lastly, the eventual laboratory investigations that are effectively necessary for the understanding, quantification and documentation of phenomena of deterioration. Thus, sophisticated investigations should be avoided for problems which, often, require already acquired knowledge and simple, trusted and widely consolidated analytical procedures" (Cecchi, Gasparoli, 2010, 25).

40 The term "environment" intends the whole of climatic, natural and anthropic factors of this cultural patrimony and that on it have physical, chemical and mechanical effects. Gasparoli 2010, 53-157.

41 The petrographic study of the rocks of the walls of Pompeii, led by Lorenzoni, Zanettin, Casella, and published in 2001, identified the rock generally defined as "tuff" as "ignimbrite campana".

42 The importance of the role of the survey is clear. The activity of analyzing deterioration has for some time been recognized for its multidisciplinary aspect, and, as such, should be taken on by a team made up of several expert figures in this field (Cecchi, Gasparoli, 2010, 46-47) 
Fig. 11. Evaluation of the intensity of the phenomenon of biological colonization on the stone surface. Image A: Wall surface of the Left Bastion of Porta Nola. Image B: wall surface of the section between Porta Nola and the left Bastion red to the consequences of the same on a wall section: in the first case the phenomenon should be noted as deterioration, while in the second case the presence of lichens could be insignificant and linked to variable phenomena over time.

Besides the distinction between alteration and deterioration, as defined in the Recommendations NORMAL - 1/88 and later UNI $11182 / 2006^{43}$, the survey team must therefore be able to distinguish the insignificant presence of a phenomenon.

Given the considerations made herein regarding the evolving nature of these phenomena from an alteration to deterioration, and given their seasonal nature, we opt to document and catalogue a form of alteration/deterioration only when it manifests over an established inferior limit.

This limit is qualitative and takes into consideration:

- the natural alteration of stone material with phenomena of alveolarization, seen in tuff, and disintegration, in particular seen in Sarno limestone;

- the natural formation of phenomena such as the presence of mold and biological colonizations which seasonally reappear on the surfaces.

It has been observed, for example, the appearance of the phenomenon of biological colonization on various wall surfaces (Fig. 11): the surface facing North of the left bastion of Porta Nola (Fig. 11a) shows this form of alteration which is widespread on almost all the squared ashlars; the surface of the section of walls between Porta Nola and the left Bastion (Fig. 11b) shows a relevant intensity of the phenomenon on the summit ashlars (more exposed to meteorological events) and it is such that it should be considered deterioration, while a lesser intensity on the lower ashlars can be described as an alteration.
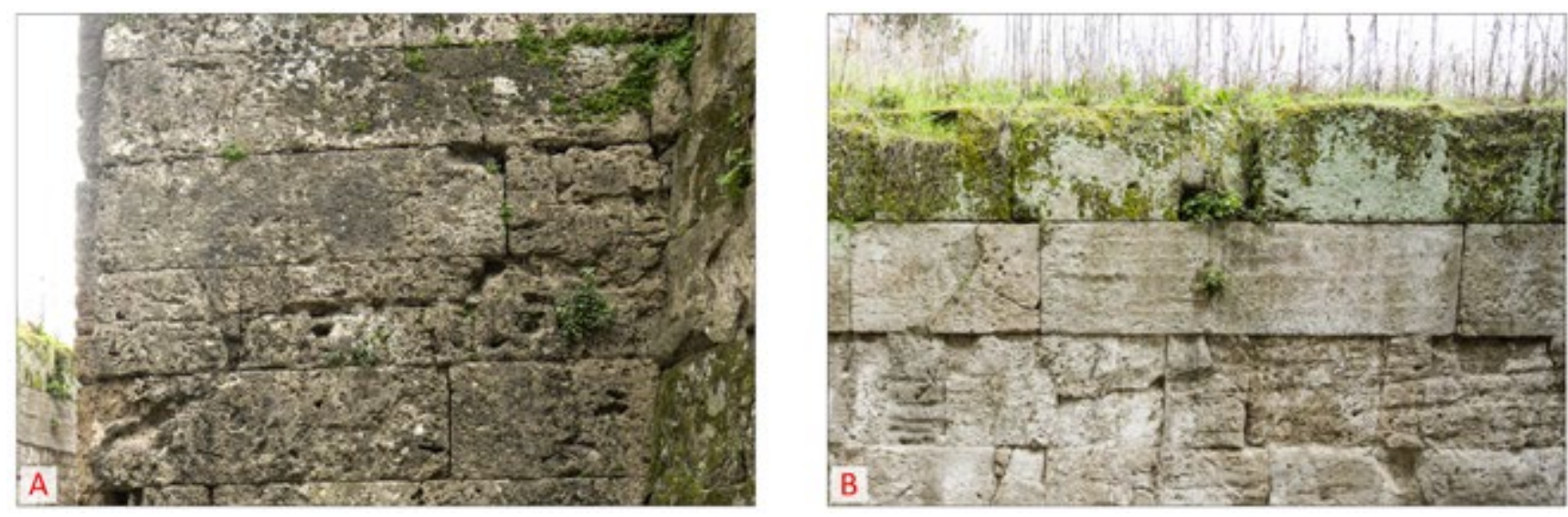

43 Terms in line with the regulation UNI 11182 del 2006:

- alteration: modification of a material that does not necessarily imply a worsening of its characteristics from a conservation point of view.

- deterioration: modification of a material that leads to a worsening of its characteristics in terms of its conservation profile.).

To define, instead, the alterations of the static balance of the structures, structural instabilities. 
The pinpointing and description of a deterioration sequence ${ }^{44}$ that characterizes the artifact makes up the basis for the qualitative differentiation of the intensity of the typical phenomena of this patrimony.

If external and/or sudden actions are excluded, such as earthquakes, anthropic actions, etc., the phenomena found in the walls are the result of the natural deterioration of the material, in turn influenced by the environment and anthropic interventions. The analysis of the evolution of the deterioration phenomena starts from a "zero" moment in which the building material was placed and the building history of the architectonic artifact begins. A condition of "absence of alterations/deterioration" is an ideal that cannot be found in reality. Building materials, in fact, in the exact moment in which they are made, have defects connected to extraction techniques, their processing, transport, etc. ${ }^{45}$. With the beginning of the life of the artifact, also the first forms of alteration of the material begin, which then develop into forms of deterioration, until they become, in some cases, also structural problems.

In the circle of walls of Pompeii, and in particular for Porta Nola, it has been observed that phenomena of physiological aging ${ }^{46}$ of the stone material favor the formation of minor vegetation and the activation of phenomena of deterioration such as the alveolarization and superficial disintegration. The increase in the presence of weeds leads to the formation of further empty spots and missing pieces of material, worsening the state of deterioration. Furthermore, it is frequent to see the superficial stone material detach, which, in some cases, are like superficial sheets several centimeters thick.

These detachments, if considerable, can lead to the weakening of the resistant section of the walls, with possible problems of instability and the formation of cracks and deep lesions in the blocks.

The observation of this case in the city wall circuit has led to categorizing the deterioration sequence shown in Figure 12. The following five phases have been established:

- Phase zero. The urban walls of Pompeii are generally made up of large blocks placed using the opus quadratum method. The stone material is generally travertine in the lower blocks and tuff in the upper blocks. The hypothesis of the

44 On the analysis of the evolution of phenomena of alteration of the stone material see the wide treatment of this subject in the literature (Fiorani, 1997, Gasparoli, 2010, Torraca, 1991, Torraca et alii, 2002).

45 "The state of deterioration of the stone materials used in construction is the result of an "alterative history" which begins at the moment of their mining: already starting with this operation, in fact, tensions and latent fractures are introduced into the material which can be more or less superficial, and that favor in a significant way the following action of the agents responsible for the deterioration".(Vallario, Del Gaudio, 45).

46 Torraca et alii, 2002.ò 

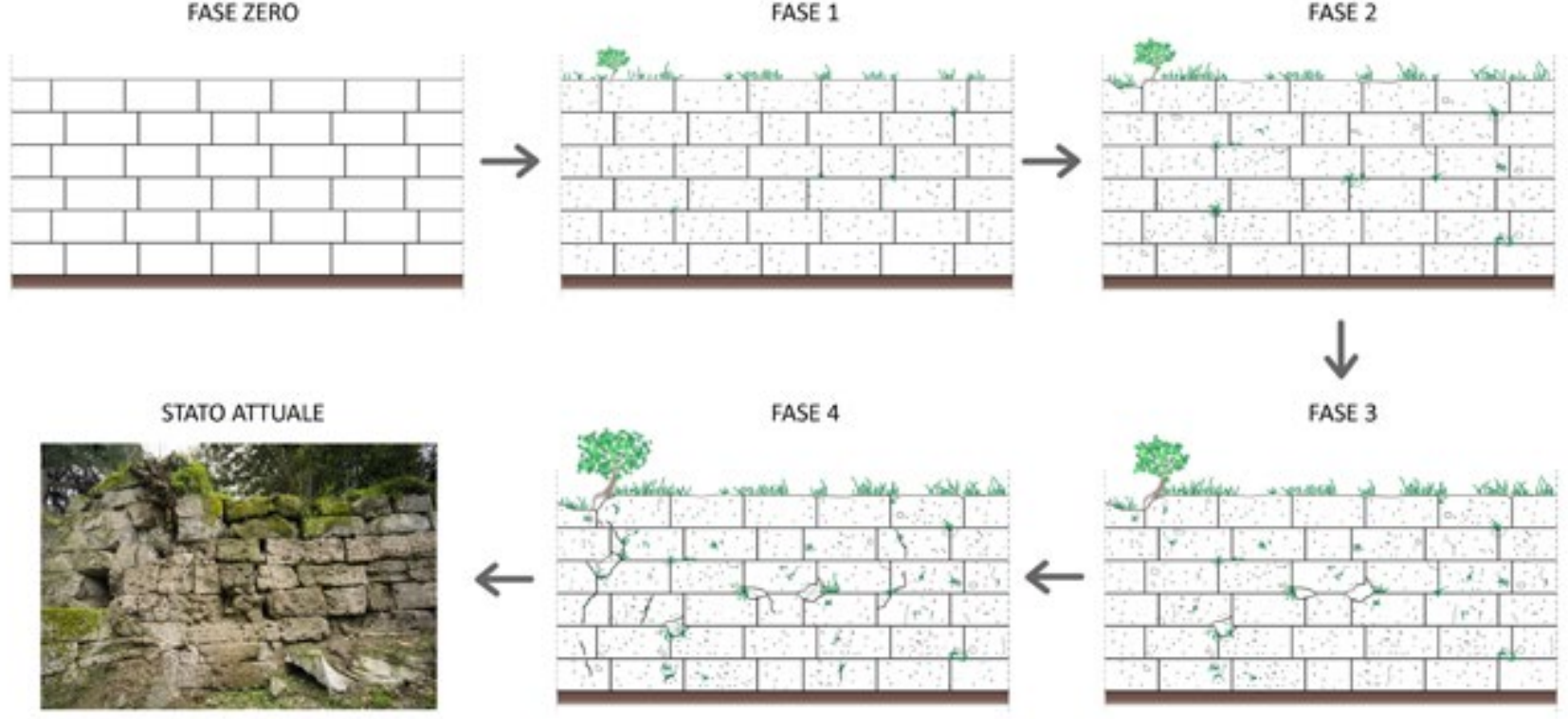

Fig. 12. Study of the "sequence of deterioration": the evolution of the phenomena of material deterioration degenerative sequence of the phenomena of alteration and deterioration begins with an "ideal" phase in which there are no such phenomena present.

- Phase 1. First phenomena of alteration: the formation of an early phenomenon of alveolarization and disintegration of the surfaces of the ashlars; the formation of weeds on the top of the wall and in the spaces in between the ashlars.

- Phase 2. Worsening of the phenomenon of alveolarization, with the formation of empty spaces of a few centimeters. The weeds get more dense and begin to occupy the spaces created inside the stone ashlars. The roots of shrubs, growing, cause damage in some stone ashlars with the loss of the material.

- Phase 3. A worsening of the already present phenomena: the alveolarization and the surface disintegration intensify with the subsequent significant loss of stone material and the formation of larger dimensions of missing material; the weeds spread inside the empty spaces; the bushes grow causing more loss of material; cracks form in the most vulnerable blocks.

- Phase 4. Last stage of the "deterioration sequence" which corresponds to the current state. The phenomena of alteration and deterioration can worsen until the extreme condition of a collapse. There are important cracks in the stone blocks; significant loss of material with weakening of the resistant section; deep breaks in the wall facing, and loss of the stable conditions of the wall.

The phenomena of instability in the curtain walls are mainly due to external forces such as pushing from the land and plant roots, also of tall trees, present in the agger and in the land between the two curtains. These pushes appear as cracks in the single square blocks and displacement, with the subsequent enlarging of the joints. This phenomenon is particularly evident in and around Porta Nola, in the area to the North where there is a wall structure that includes a "drainage canal 


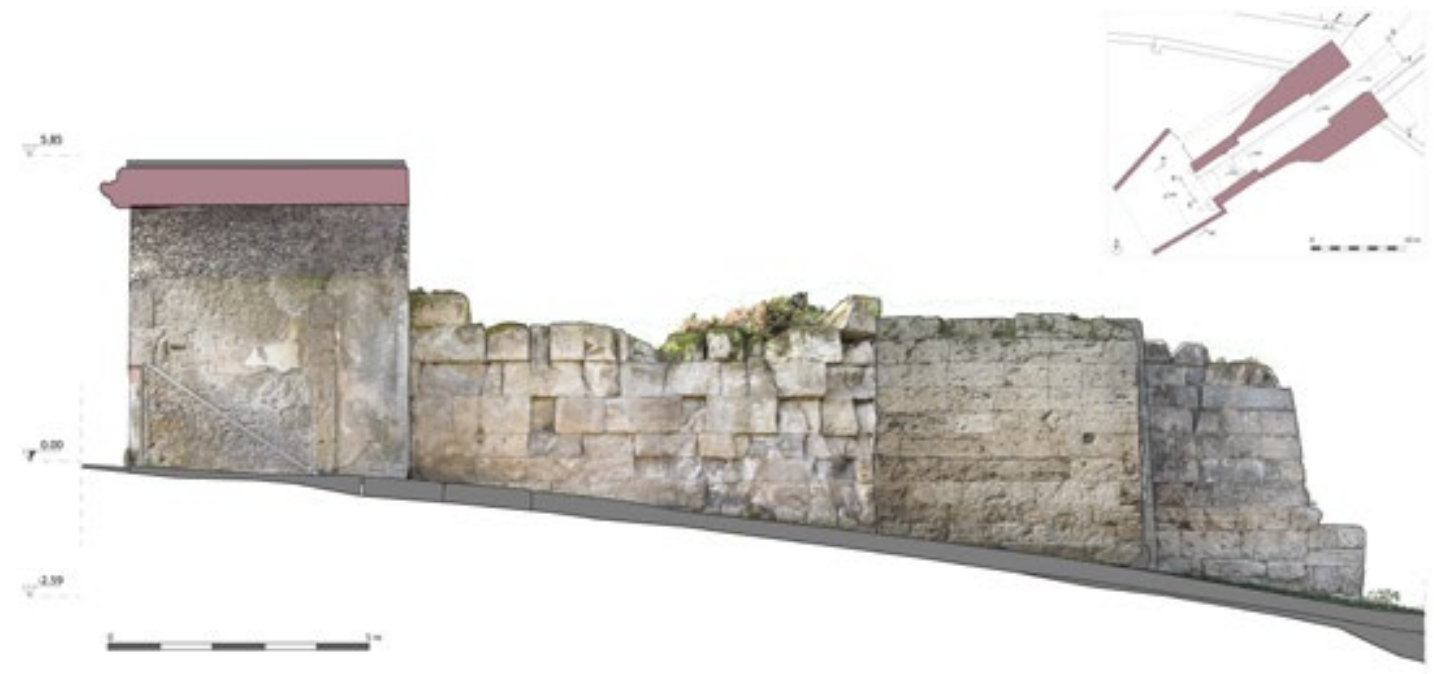

Fig. 13. Porta Nola,

longitudinal section

Photomap created in

September 2017

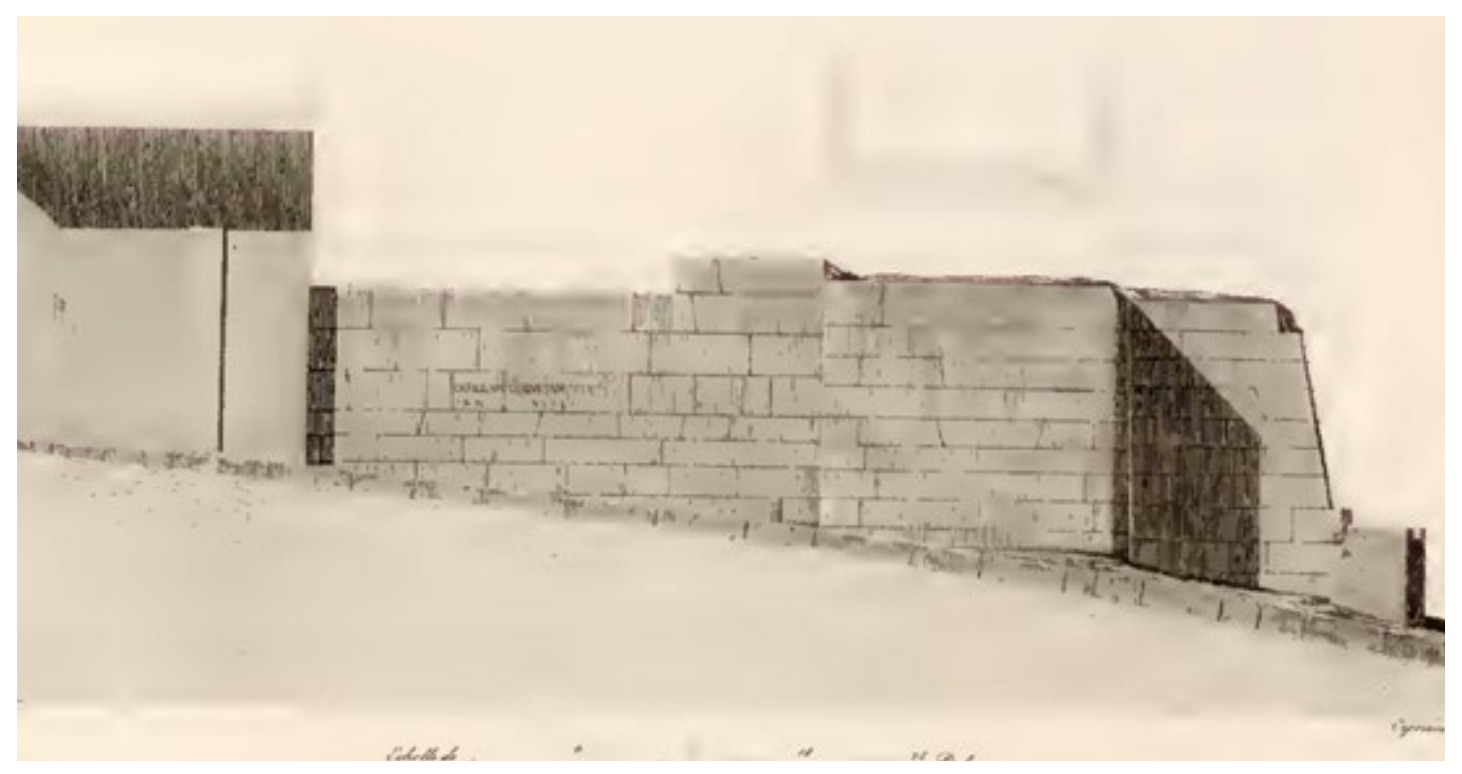

Fig. 14. Porta Nola, longitudinal section,

Mazois, 1812, Tav.

XXXII

Fig. 15. Porta Nola, longitudinal section by Maiuri, 1930, Tav. XI

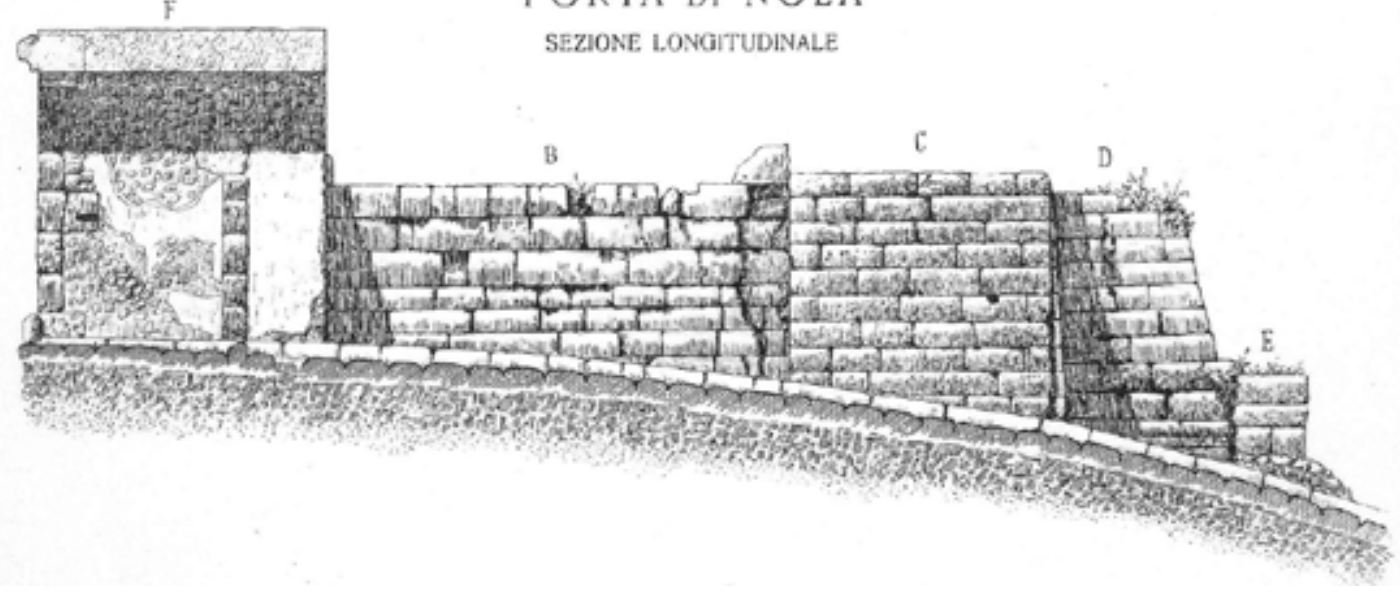


for rain runoff" ${ }^{n}$ the crack in the wall facing is a deep break which goes up almost vertically (Fig. 15-16).

The analysis of the conservation state of the wall structures of Pompeii cannot be removed from considering the entire history of the city. This history is divided into two distinct eras: the first regarding the ancient city, engulfed by the ash of the eruption of Vesuvius in $79 \mathrm{AD}$, the second regarding the rediscovery of the city and, therefore, closely linked to the history of the archeological excavations. As early as 1763 , Fiorelli wrote about the excavation of the wall circle: "Scoverte della Porta occidentale" ${ }^{48}$. De Cesare, in 1845, told of the discovery of Porta Nola (or Porta di Iside): "It was a tentative little dig in 1813 towards the North of Pompeii, in continuation of a gate found along the walls of the City, which was called d'Iside for the head of this Goddess which was found carved into its summit.".49.

While of the first period we do not have many written testimonies, the phase of the excavations is widely documented with descriptions, graphic representations, maps, news, etc.

The reconstruction of the historic-building phases, as formulated by Maiuri, finds a continuation in the phases following the moment of the excavation. In fact, the descriptions and the depictions provide "photographs" of the relics at the moment of their discovery and allow for the study not only of the restoration works that followed, but also of the evolution of the conservation status of this patrimony.

The phenomena which have been found are mostly "static", in a slow and natural evolution of the material and structural deterioration. In some sections, the transformation of forms of alteration into deterioration is more noticeable, a symptom of various factors such as the lack of conservation interventions.

Thus, the concept of historization of the deterioration can be introduced, according to which the phenomena found have already been documented in the historic sources, more or less recently. This idea requires a careful definition of the seriousness of the phenomenon and the urgency of intervening.

Porta Nola represents an important case. We compared the wall structures in their state of deterioration investigated in September 2017 (Fig. 13) with what was described by Mazois in 1812 (Fig. 14) and what was presented by Maiuri in 1930 (Fig. 15).

From the investigation of the deterioration done in September 2017, there are some forms of alteration in an advanced state and forms of deterioration which are very advanced, including alveolarization, disintegration and detachment of stone material,

\footnotetext{
47 Maiuri, 1930, Tav. X, letters E and F.

48 Fiorelli, 1860, 146.

49 De Cesare, 1845, 87.
} 
real missing parts of the material which have caused the instability of some ashlars and the formation of deep breaks.

The section of Porta Nola depicted by Mazois does not describe the beginning of cracks in the wall facing. In this case, it can be assumed that this phenomenon, today very evident, occurred after that date. It is necessary, however, to reflect on the reliability of the source. Mazois, in fact, in depicting Porta Nola, made a few errors in the planimetry.

A little more than a century later, Maiuri carried out the material survey of Porta Nola with great precision. The squared ashlars of the wall can be seen as well as the plastered sections of the arch of the gateway, the forms of deterioration. The missing materials, the cracking of the blocks and the deep breaks along the joints are already evident.

The comparison between the current state of conservation and the state depicted by Maiuri confirms both the reliability of the source and the history of
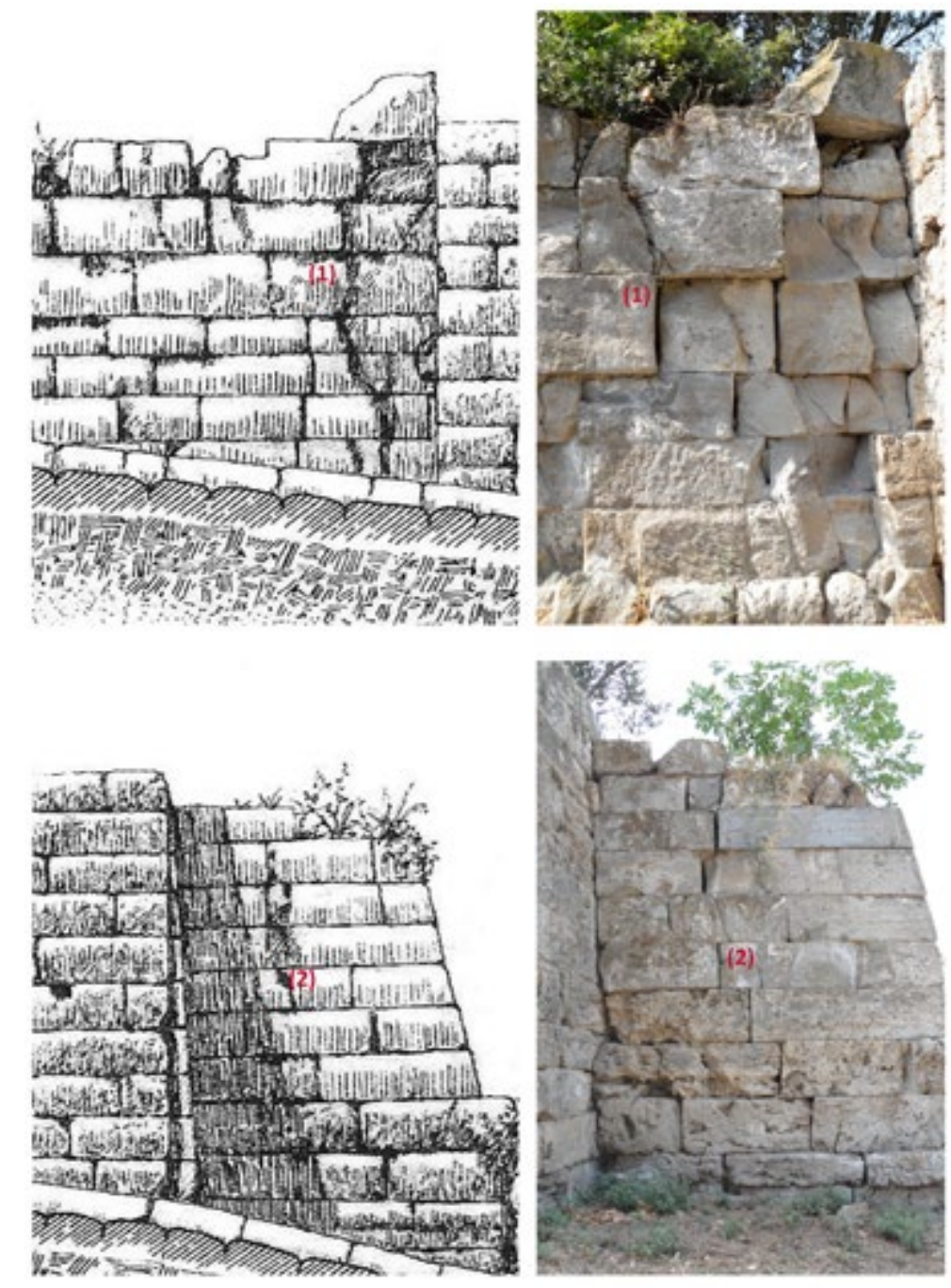
this deterioration.

In the enlargements at the top of Figure 16, you can see the lack of considerable portions of material in the blocks closest to the break in the curtain wall, represented by the bastion in Sarno limestone. The situation had already been depicted in a less serious form by Maiuri in 1930. The images at the bottom show the phenomenon of static instability of the wall structure which allows for the drainage of rain runoff. This phenomenon, already depicted in 1930, consists in a collapsing of the freestanding end of the structures, identified by a deep break. Furthermore, in the upper part of the wall, some shrubs are visible. The plants have compromised the Fig. 16. Comparison between the representation by Maiuri from 1930 (on the left) and the state of the wall in September 2017 (on the right).

Above: wall structures near the left bastion of Porta Nola. Under: structure for runoff water near

Porta Nola conservation and the stability of the upper tuff blocks, which result as being further deteriorated in comparison to what was depicted by Maiuri. 


\section{A new proposal for the evaluation of the wall risk index: from the de- finition of macro-elements to the vulnerably index.}

The study proposed aims to provided a graphic map of the level of risk of the parts that make up the architectonic artifact, through a visualization using a chromatic scale of increasing intensity.

This project has four procedural phases:

1- Definition of the macro-elements

2- Evaluation of the types of damage found on each single surface

3- Definition of an index of vulnerability

4- Definition of a risk index

The first phase aims to overcome the problem of the two dimensional reading of

Fig. 17. Planimetry of the architectonic complex of Porta Nola with the identification of six macro-elements

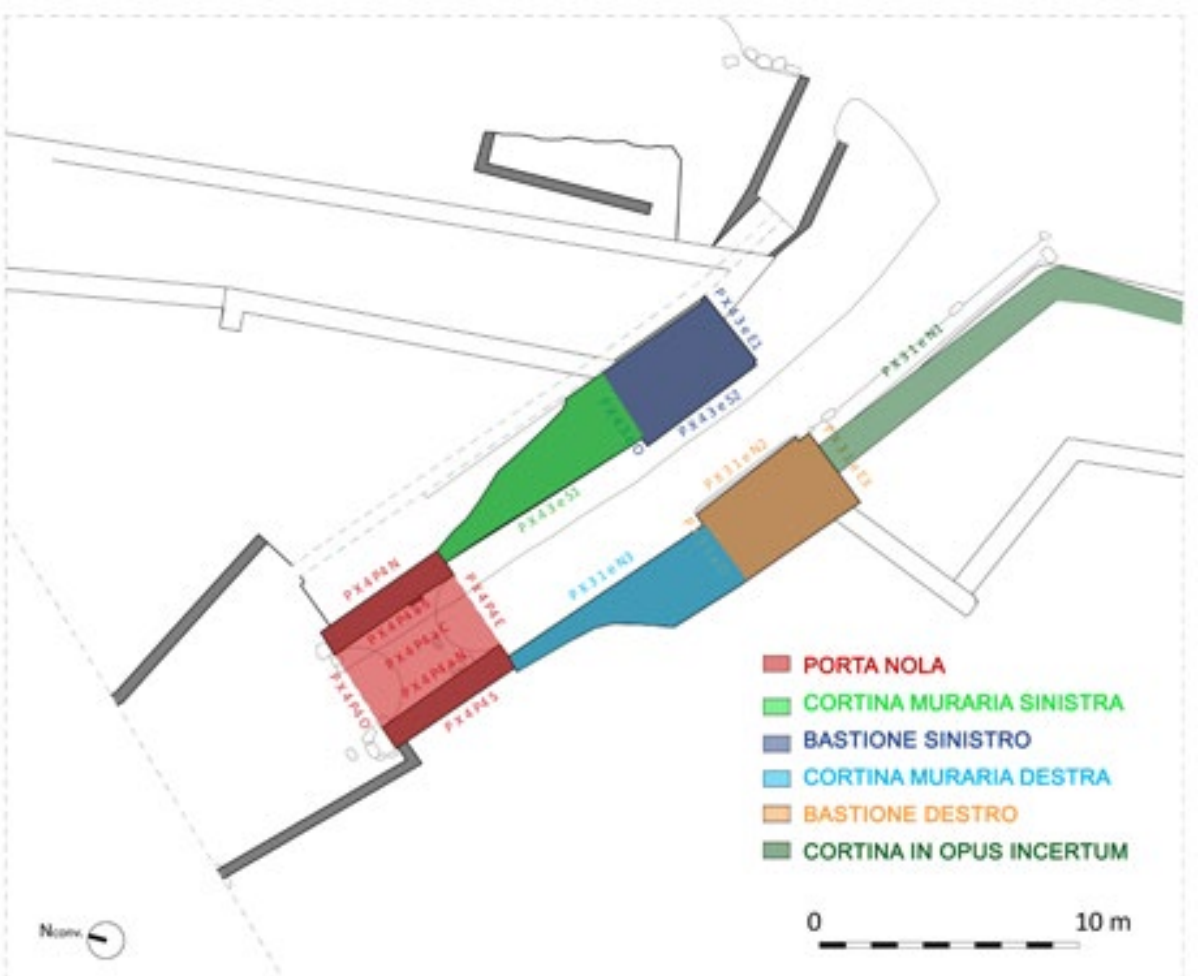

The two dimensional study of the conservation status can be overcome with the definition of macroelements, as proposed by Doglioni: "constructively recognizable and finished part of the artifact that can coincide - but not necessarily coincide - with an identifiable part also in architectonic and functional terms (ex. facade, apse, chapels) (...) to make up a part constructively unitarian and, in some cases, volumetrically defined, even if in general connected to and not independent from the overall construction" ${ }^{\prime 50}$.

50 Doglioni, Moretti, Petrini, 1994, 71-73 
The survey, the analysis of the materials and of the building techniques, the study of the building typologies and the historic-construction evolution of the building are preliminary operations to the pinpointing of the macro-elements that make up the architectonic complex ${ }^{5 !}$.

From these phases comes the definition of the parts that are constructively recognizable and finished of the architectonic complex of Porta Nola (Fig. 17). Thus, six macro-elements can be recognized: Porta Nola, the curtain wall to the left of Porta Nola, the left Bastion, the curtain wall to the right of Porta Nola, the right Bastion, and the curtain wall in opus incertum. The macro-elements determined are modular and the architectonic surfaces that outline them can be measured directly (Fig. 21). Only these surfaces, in fact, can directly and easily be investigated in terms of an analysis of the conservation status.

Each surface was given an anagraphic code, a sort of identity card that allows it to be pinpointed inside the archeological site of Pompeii.

The cataloguing of each individual surface includes a description of its materials and building technique, besides the identification of the forms of alteration/ deterioration present both on the architectonic surface (if present) and on the wall structure, the criticality of the phenomenon (structural, material, technological, of use, of the seriousness (low, medium, high) and of the urgency (low, medium, high)) $)^{52}$.

The second phase of the process includes a detailed study of the building techniques used for the creation of the construction and of the possible mechanisms of damage. Besides the predisposition of the artifact to develop certain damage mechanisms (typical vulnera-

51 A wide bibliography exists, please see, for the definition of the concept of macro-elements and the description of different behaviors and cracks manifested that are a result of it. See Doglioni 2000 and the relative bibliography.

52 For a discussion on the concepts of seriousness and urgency please see Cecchi, Gasparoli, 2010, 52-53.
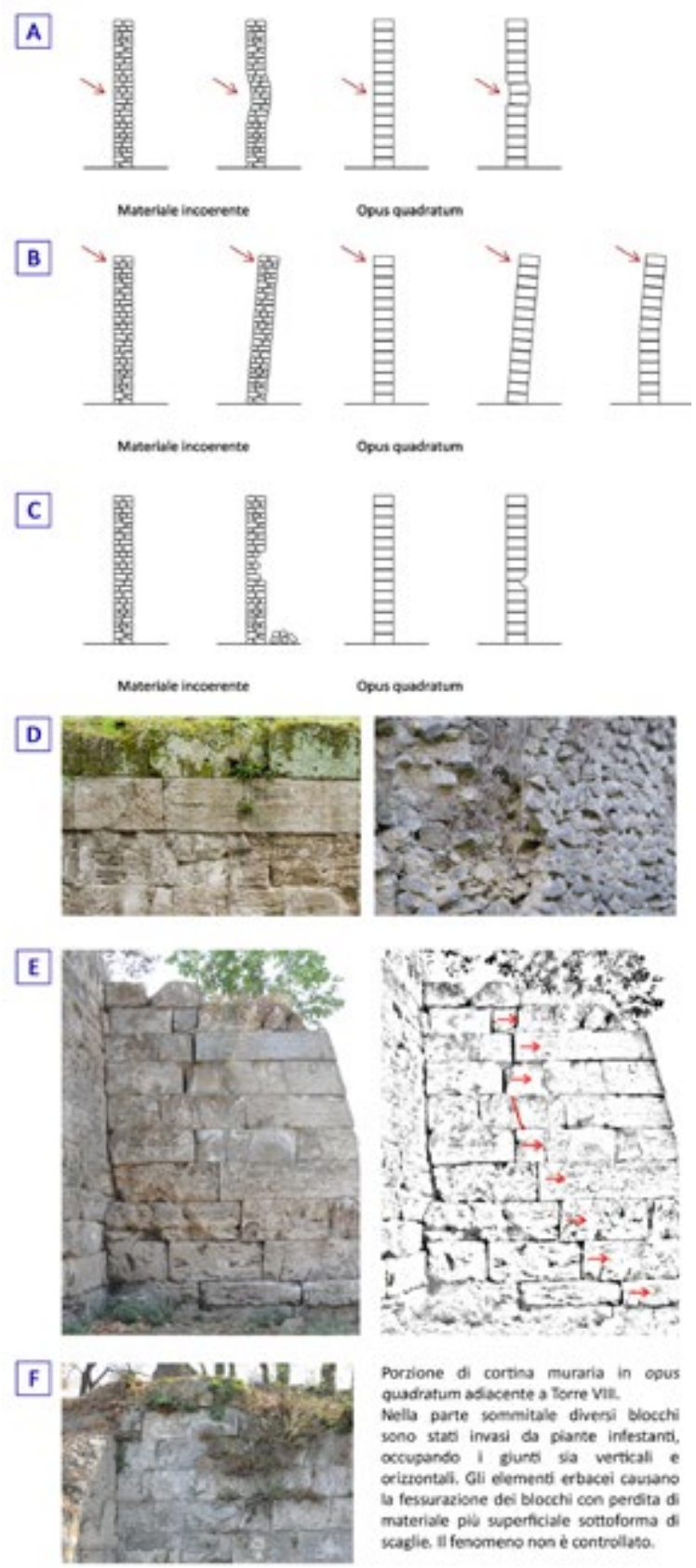

Porsione di cortins muraria in copus quadratum asicente a Torre vis. Nells parte sommitale diveni vloceti sono stat invasi da plante infestanti, occupando I giunt sa vertical e
critrontali. Gli elementi erbacei caviano a fessurazione des blocchi con gersita d materiale pis resperficiale sottoforma di materiale pio superficiale sottoforma
vaglie, if fesomeno nos è controllata.
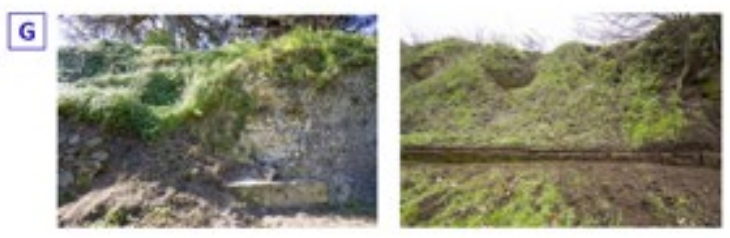

Fig. 18. Depiction of the types of damage identified in the curtain wall 
bility), particular attention should be given to the material-construction-structural aspects that influence the activation and evolution of these mechanisms (specific vulnerability).

The study of the city walls of Pompeii conducted up until now has led to the identification of eight different types of recurring damage. Alongside the cataloguing of the conservation status of the architectonic surfaces, there is an ulterior catalogue identifying the possible types of damage, as well as the seriousness, extension and urgency of the phenomenon. The types of damage identified (Fig. 18) are:

\section{a) Deformation}

The deformation of the wall complex can be found in cases in which there are localized pushes not on the top or significant weight in certain points. In both cases, force is applied to the wall that induces a state of pressure-bending tension which deforms the wall structure. The phenomenon can more clearly be seen in cases in which the wall has more light free from inflection, reduced thickness and good consistency.

In the case of a wall element made from heterogenous stone material attached with poor quality mortar or without any mortar (opus incertum), such actions provoke instability in the single ashlars and collapse in the most serious cases of instability. In the case of wall facing in opus quadratum, done with big squared off blocks, this deformation manifests in a "localized section out of plumb" which affects the single block.

\section{b) Out of plumb}

In the case in which the wall facing can be considered as a rigid body, the activation of rotation hinges that manifest as the wall is leaning out of plumb is considered to be a high risk factor which leads, in the worst case scenario, to the collapse of the portion of wall facing. The seriousness of the phenomenon is measured through the qualitative evaluation of how far out of plumb it is ${ }^{53}$.

c) Loss

The loss of stone material can lead to both the reduction of the resistant section of the wall and the instability of portions of the stone work with the possible consequent collapses. The seriousness of the phenomenon is evaluated based on the surface expanse of the macro-element in question and on the type of loss (low if the loss of material is superficial, medium if the loss of material is considerable, high if the stone element is partially or completely absent).

53 It is important to remember that, with this case, the curtain walls were created with a light "inverse out of plumb", which allows for the push of the land between the two curtain walls to be contrasted even more. 


\section{d) Superficial cracks (cracks in a single brick)}

The evaluation of this phenomenon is different according to the type of wall surface being investigated.

In the case of the curtain wall in opus quadratum, the phenomenon of superficial cracks is identifiable through the breaking of the squared off block (fracture).

In the case of the curtain wall in opus incertum the "crack" can affect the external wall surface (and be visible) or the internal nucleus.

e) Deep breaks (cracks in the actual wall)

The evaluation of this phenomenon is different based on the type of wall surface being investigated.

In the case of the curtain wall in opus quadratum (consisting of a thickness equal to a single squared off block), the break in the wall usually manifests as a horizontal dislocation of the square blocks with a consequent significant widening of the bonds. Only in some cases do these cracks go through the blocks causing a break which usually goes vertically up the wall.

In the case of a curtain wall in opus incertum, instead, the break goes through both the external facings and the inner nucleus.

\section{f) Presence of vegetation}

The presence of vegetation is one of the most variable phenomena over time that can be found in the curtain wall. It is for this reason that it is also one of the most dangerous phenomena. Among the most damaging effects is the mechanical push of root systems, which causes the loss of stone material and, in the worst cases, the instability of the blocks and whole portions of the curtain wall. ${ }^{54}$

g) Instability of the slope

Due to the particularity of this site and the typology of the artifact being investigated, one of the biggest criticalities is linked to the instability of the lands that make up the agger and of the land between the two curtain walls. In some cases, this phenomenon appears contained, in other cases it extends along the curtain wall.

\section{h) Disconnected Elements}

Frequently, due to various factors, some blocks of the curtain wall are uneven or poorly connected to one another. These elements are a risk factor that should not be ignored as they could result in materials falling from above.

54 Torraca, 1991, Torraca et alii 2002. 
Fig. 19. Formulae for calculating the vulnerability index
Each type of damage is associated with a point system that goes from 1 to $5 \mathrm{ac}-$ cording to the seriousness and expansion of the phenomenon. The evaluation of the parameter regarding "urgency" is strictly dependent on the experience of the evaluator in reading and interpreting the individual phenomenon.

The third phase gathers the data catalogued during the identification of the type of damage, of their seriousness and urgency, through the definition of an index of vulnerability determined for each wall surface. (Fig. 19). This value is equal to the relationship between:

- the total number of points assigned to each type of damage (Pi) times the corresponding value of urgency (ui);

- the maximum value of vulnerability possible, represented by the product of the number of types of possible damages (n), the maximum value of urgency $(\operatorname{umax}=3)$ and the maximum value of the seriousness of the phenomenon (equal to 5).

The vulnerability is therefore expressed as a value from 0 to $1 . .^{55}$

\section{INDICE DI VULNERABILITA'}

\begin{tabular}{|c|c|c|}
\hline 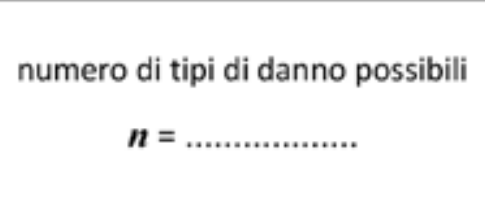 & 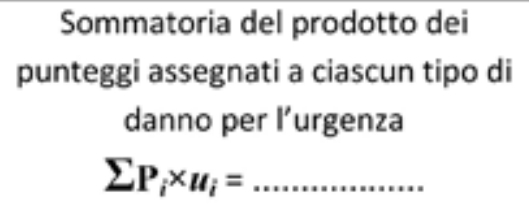 & $v_{k}=\frac{\sum_{i} P_{i} \times u_{i}}{3 \times 5 n}=\ldots \ldots$ \\
\hline
\end{tabular}

The fourth phase consists in the aim of going beyond the reading of the architectonic surfaces conducted up until now as part of the Plan of Knowledge of the Great Pompeii Project, putting together in a single numeric value the values of surface vulnerability linked to the same architectonic macro-element.

To reach an overall and easy to use evaluation, having as a reference what has been set forth in the Sheet A-DC, "Sheet for the Surveying of Damages to Cultural Patrimonies - Churches" 56 , in particular in section A17 regarding the calculation of

55 The definition of an index of vulnerability of the wall structures is an issue which has been examined extensively in literature. Regarding this, see Benedetti, Petrini, 1984: 66-74; Rischio sismico di edifici pubblici; Repertorio dei meccanismi di danno; Tempesta, 2011: 13-16. In the case presented here, it should be specified that it is a simplified evaluation, which allows for quick early results to be obtained of the evaluation and it is easily updatable.

56 The model of the sheet is the one attached to the D.P.C.M. 23/02/2006, which was then republished in Attachment I of the Dir. Min. Beni e Att. Culturali 12/12/2013 and, later, inserted into the Dir. Min. Beni e Att. Culturali 23/04/2015. 
the damage index ${ }^{57}$, it has been agreed upon to calculate the value of the risk index as the weighted average, in relation to the breadth of the architectonic surfaces that make up the macro-element, of the vulnerability indexes.

$$
r=\frac{\sum_{k} v_{k} S_{k}}{\sum_{k} S_{k}}
$$

Where: r: vulnerability index of the macro-element; vk: vulnerability index of the surface k-th of the macro-element; Sk: surface k-th

In this way it is possible to come up with a risk index of the single macro-element using a number that ranges from 0 to 1 . The higher the risk, the more urgent an intervention on the macro-element is.

Fig. 20. Reading of the conservation state of the architectonic surfaces depicted in the internal perspective of the macro-element of Porta Nola. Surface $P$ $\times 4 P 40$

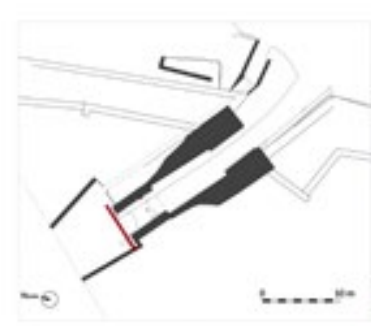

\section{LEGENDA DEL DEGRADO}

$\square$ Me2 - Avediazasose

ACS - Colonitarabione biologica

AID - Deposito soperficiale

Al1 - Dagespatione

A12 - Distacco

Al3 - Emorescenda

Ald - Erosione

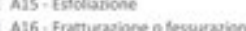

A17. Fromedifsesite

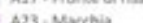

A24. Mancana

A30 - Presenca \& umidre

A31 - Presenta of vecemazions

A32. Reintegratione con myiervi nen idone

IEGENDA DEI DISSESTI

PC B1-Crollo

(1) 62 -Detormutione

II 63 - fucri piombe

Ba - Levionent

65 - Lesiene passame

ALTRE FORME DI DEGRADO

CI-Deposio di munerise do rimumer

Elemens somess
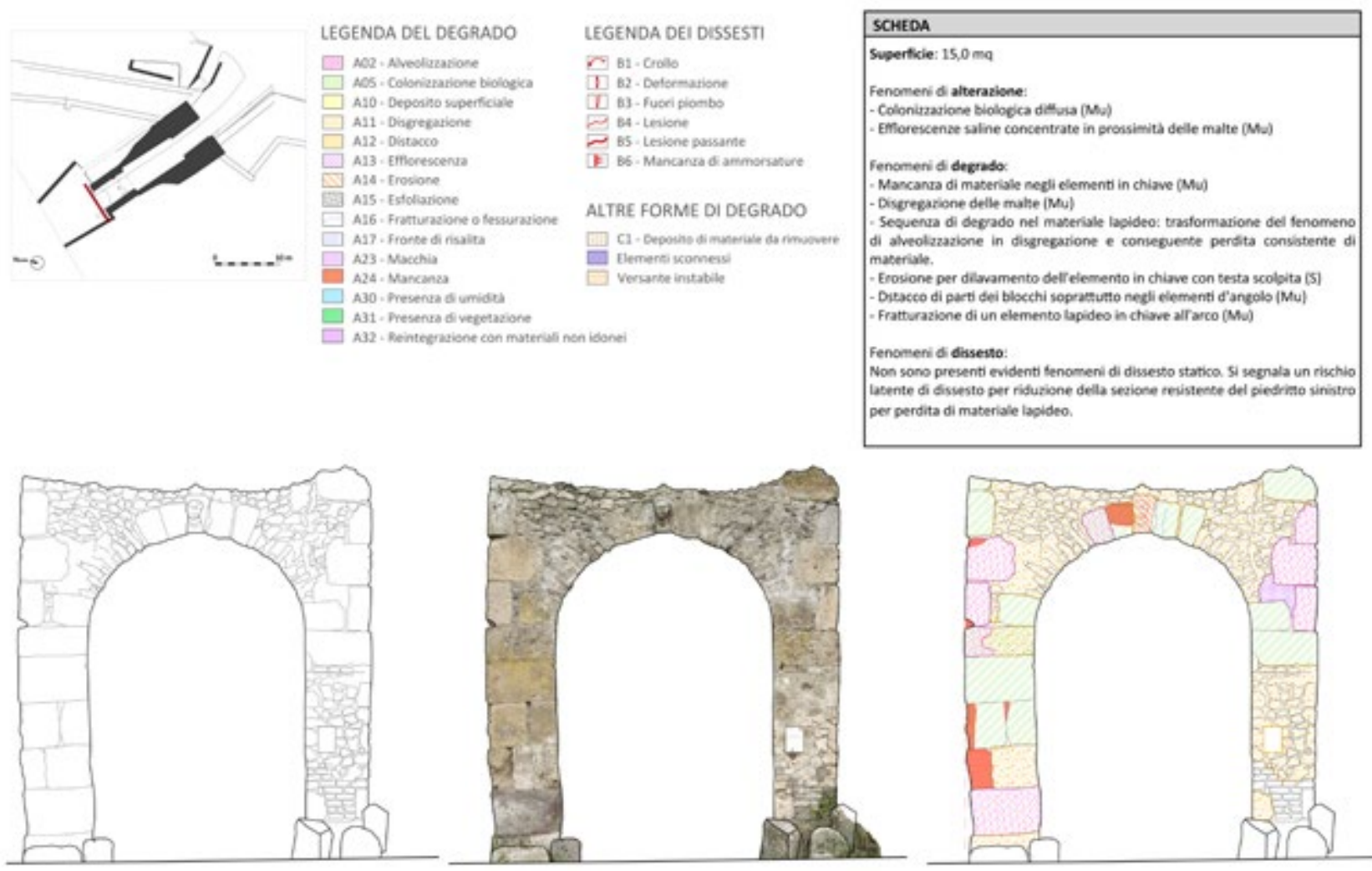

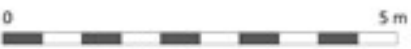

57 Please see the Gazzetta Ufficiale n. 231 of 02/10/2013 the D.P.C.M. 13/03/2013, in «Approval of the manual for the filling out of the sheet for the survey of damage to cultural patrimonies, Churches (model A-DC)». 


\section{Application of the calculation of the risk index in the case of Porta Nola}

The study of the state of conservation of each architectonic surface is preparatory to the definition of the risk index. The phenomena of alteration and deterioration are catalogued according to the classic definition of the UNI 11182/2006 (Fig. 20).

The macro-element made up by Porta Nola includes seven architectonic surfaces (Fig. 21). Along with the cataloguing of each surface using the classic method of mapping the deterioration, then follows the definition of the vulnerability index of the surfaces, applying the formula defined previously.

Figure 22 shows the table containing, for each surface, the numerical values associated with each type of damage and the consequent value of the vulnerability index of each surface that makes up the macro-element. The weighted composition of the values obtained allows for the definition of the risk index which, for the macro-element of Porta Nola, results as equal to 0.035 (Fig. 23) and is represented with a single yellow color in the figure.

It can be seen that, overall, the macro-element "Porta Nola" has a minor risk index. The assonometric projection highlights each single surface for which the vulnerability indeed ranges from low (regarding the vertical surfaces inside the gate that have some degree of protection from outside elements) to minor (regarding the outer surfaces).

Thus, this highlights a conservation status which is generally good, due also to the effects of the recent restoration and conservation interventions.

This procedure, repeated for each surface and for each macro-element, allows for the definition of a vulnerability index of each surface and a risk index of each macro-element.

Using a planimetry of the results on a chromatic scale, it is immediately possible to pinpoint the macro-elements that are most at risk (Fig. 24-25).

Color coding seems to be effective and immediately communicates the degree of risk of each macro-element. In particular it can be seen that:

- the macro-element "Porta Nola" has a minor risk index, and a conservation status that is generally good. The surfaces inside the gate, in particular, thanks also to being more protected from the external causes of deterioration, show a low vulnerability index;

- the Bastions have a moderate risk index, but from the analysis of the vulnerability indices of each wall it can be seen that the Left Bastion (North) has a surface with very serious vulnerability, a symptom of a worse conservation status and instabilities that have been found; 

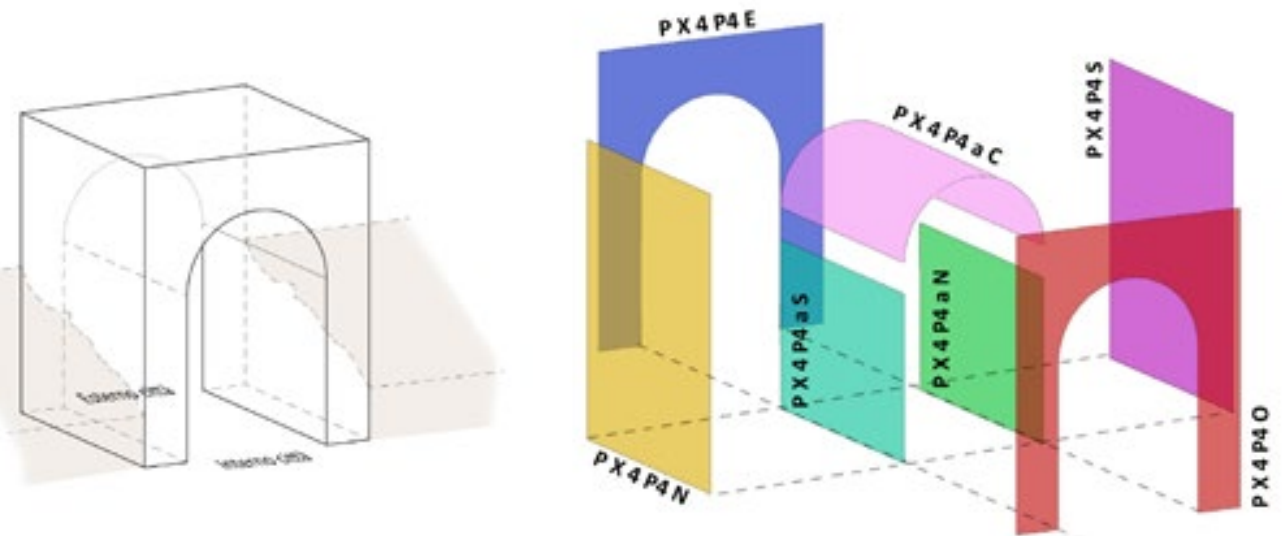

Fig. 21. Composition of the surfaces of Por ta Nola for defining the macro-element

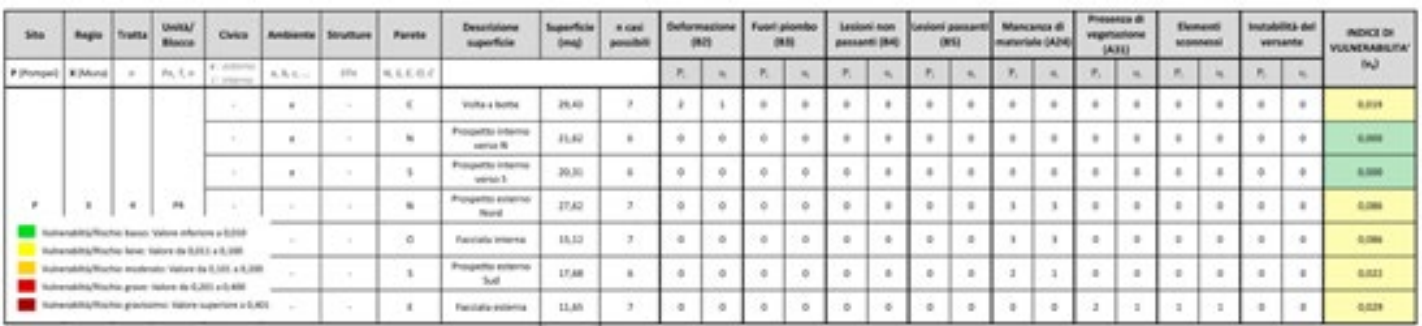

Fig. 22. Table for calculating the vulne rability index of the surfaces making up the macro-element Porta Nola

Fig. 23. Macro-element Porta Nola with chromatic indications of the risk index (on the right) derived from the makeup of the vulnerability indices of each surface (left)

Fig. 24. Chromatic scale of the risk index of the marcoelements making up Porta Nola 


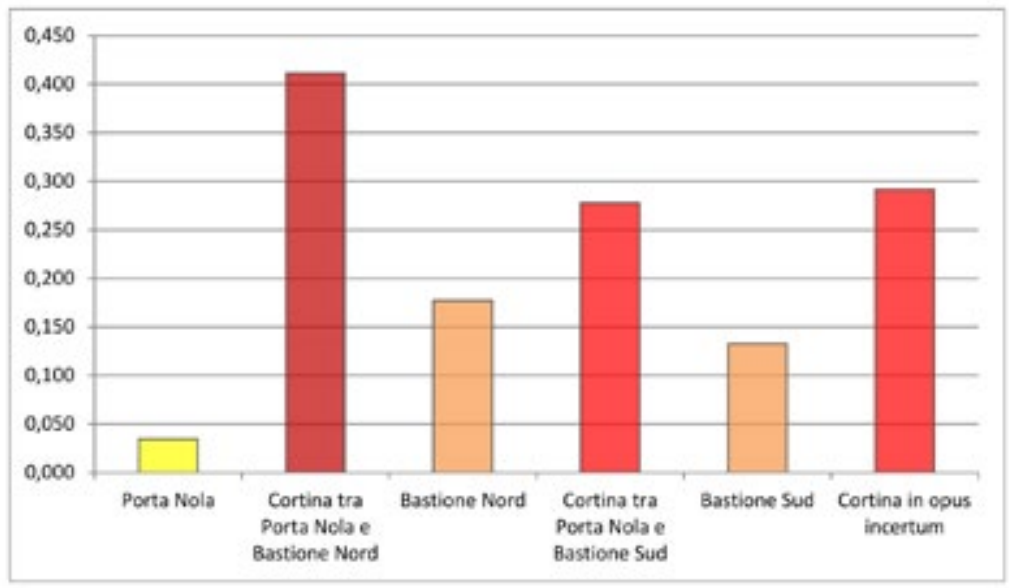

Fig. 25. Chart of the risk indices of the macro-elements making up Porta Nola.

- the macro-elements between the gate and the bastions have a serious risk index for the southern wall and a very serious one for the northern wall;

- the macro-element outside the gate represented by the curtain wall in opus incertum towards the south, has a serious risk index.

On a scale of seriousness and therefore easily identifiable, the macroelement with the worst conservation status is the wall between the gate and the northern bastion.

On a scale of priority for an intervention, it must be taken into consideration that this section of wall is the most critical, followed by the macro-elements at serious risk and then the moderate ones. Porta Nola, which has a minor risk index, is also the macro-element which has been conserved the best.

\section{Final considerations}

The most advanced surveying methods have allowed for a reading of the conservation status of this architectonic complex to be fast and detailed, integrated with observations and the cataloguing of the architectonic surfaces in the field. A methodology of analysis, therefore, that is rapid and non-invasive, capable of providing immediate data for the study of materials, techniques and building history of this architectonic artifact.

The approach of mapping the deterioration of the surfaces has been surpassed also thanks to the three dimensional reconstructions provided by the methodology of laser scanner surveying, thus allowing for these surfaces to be grouped in macroelements.

The determination of a vulnerability index of the surfaces allows for the representation with an increasing chromatic scale of the intensity of the phenomena present in the wall structure. Through the definition of the risk index of the macroelement, we tried to surpass the two dimensional analysis, visual and quick, and to provide a three dimensional vision of the phenomena and their intensity. 
Future developments of the mapping of deterioration will lead to skipping the phase of two dimensional analysis, directly developing an approach of three dimensional mapping of the forms of alteration, deterioration and instability.

Applied to the inner curtain wall of Pompeii, the method proposed here for the evaluation of the conservation status of the surfaces and for the determination of the risk index of the macro-elements could provide important information.

The goal is to define, for the entire wall circuit (sections of the wall ring, gates and towers) an evaluation of the overall risk index of the macro-elements, evaluating therefore the most dangerous situations.

The possibility to pass from the scale of three dimensional reading to that of two dimensional reading (and vice versa) also allows us to be able to pinpoint, within the macro-element, the surfaces with the most serious situations.

This process, if implemented correctly, is easy and immediately updatable, and can be the knowledge basis for a program of targeted interventions.

(L.T., S.B., M.S.)

\section{References}

Adalgisa, Donatelli. 2016. Terremoto e architettura storica: Prevenire l'emergenza, Roma: Gangemi Editore.

Anniboletti, Lara. 2015. 'Le fasi delle fortificazioni di Pompei. Stato delle conoscenza', in Siris. Studi e ricerche della Scuola di Specializzazione in Beni Archeologici di Matera 15: 49-70.

Benedetti D. and Vincenzo Petrini. 1984. 'Sulla vulnerabilità sismica di edifici in muratura: proposte di un metodo di valutazione', in L'Industria delle Costruzioni, 149: 66-74.

Besl, Paul J. and Neil D. McKay. 1992. 'A method for registration of 3-D shapes', in IEEE Trans. Pattern Anal. Mach. Intell., 14(2): 239-256.

Bochicchio, Rocco. 2015. 'Alcune note sulle marche di cava', in Siris. Studi e ricerche della Scuola di Specializzazione in Beni Archeologici di Matera 15: 45-47.

Capponi, Gisella. 2004. 'L'invecchiamento e il degrado' in Trattato del Restauro Architettonico, 8.1, edited by Giovanni Carbonara, Torino: UTET, 433-437.

Cecchi, Roberto, ed. 2011. Pompei archeologia: progetto di conservazione e fruizione del patrimonio archeologico, Milano: Electa.

Cecchi, Roberto and Paolo Gasparoli. 2010. Prevenzione e manutenzione per i Beni Culturali edificati. Procedimenti scientifici per lo sviluppo delle attività ispettive. Il caso studio delle aree archeologiche di Roma e Ostia Antica, Firenze: Alinea.

Chiaramonte Trerè, Cristina. 1986. Nuovi contributi sulle fortificazioni pompeiane, Milano: Cisalpino-Goliardica. 
De Caro, Stefano, 1985, 'Nuove indagini sulle fortificazioni di Pompei', Annali di Archeologia e Storia Antica dell'Istituto. Orientale di Napoli (AION) VII: 75-114.

De Cesare, Francesco. 1845. Le più belle ruine di Pompei, descritte misurate, e disegnate per Francesco De Cesare, Napoli: Sebeto.

Doglioni, Francesco, Alberto Moretti and Vincenzo Petrini, eds. 1994. Le chiese e il terremoto. Dalla vulnerabilità constatata nel terremoto del Friuli al miglioramento antisismico nel restauro. Verso una politica di prevenzione, Trieste: Edizione Lint.

Doglioni, Francesco. 2000. Codice di pratica (linee guida) per la progettazione degli interventi di riparazione, miglioramento sismico e restauro dei beni architettonici danneggiati dal terremoto umbro-marchigiano del 1997, Ancona: Bollettino ufficiale della Regione Marche.

Etani, Hiroshi 2010. Pompeii. Report of the excavation at Porta Capua, Kyoto: Paleological Assosiation of Japan.

Fabbri, Marco. 2015. 'Nuove ricerche per una rilettura delle mura di Pompei', in Siris. Studi e ricerche della Scuola di Specializzazione in Beni Archeologici di Matera 15: 29-47.

Fichera, Maria Grazia, Luigi Malnati and Maria Letizia Mancinelli. 2015. 'Grande Progetto Pompei: la Direzione Generale per le Antichità e il Piano della Conoscenza', in Archeologia e Calcolatori, 7: 25-31.

Fiorelli, Giuseppe. 1860. Pompeianarvm Antiquitatvm Historia qvam ex cod. mss. et a schedis divrnisqve, Napoli, vol. I.

Fiorani, Donatella. 1997. 'L'invecchiamento e il degrado', in Trattato del Restauro Architettonico, 2, edited by Giovanni Carbonara, Torino: UTET.

Galli, Claudio and Silvia Bergami. 2014. 'Processo storico-costruttivo, dissesti e consolidamento: il caso di studio del Duomo di Mirandola', in La cultura del restauro e della valorizzazione: temi e problemi per un percorso internazionale di ricerca, Atti del Convegno Internazionale sulla Documentazione, Conservazione e Recupero del Patrimonio Architettonico e sulla Tutela Paesaggistica, vol. I. Firenze: Altralinea Edizioni srl, 299-306.

Garagnani, Simone and Andrea Gaucci, eds. 2017. Knowledge analysis and innovative methods for the study and the dissemination of ancient urban areas", Proceedings of the KAINUA 2017 International Conference in Honour of Professor Giuseppe Sassatelli's 70th Birthday (Bologna, 18-21 April 2017), in Archeologia e Calcolatori, 28.

Gasparini, Valentino and Josè Uroz Saéz. 2012. 'Las Murallas de Pompeya. Resultado del sondeo efectuado en Porta Nocera (2010) y su contextualización', in Vesuviana. An International Journal on Archaeological and Historical Studies on Pompeii and Herculaneum 4: 9-67.

Gasparoli, Paolo. 2010. 'Le superfici esterne degli edifici. Degradi, criteri di progetto, tecniche di manutenzione'. Firenze: Alinea Editrice srl.

Giorgi, Enrico. 2017. 'Documentare, analizzare, comprendere. Dal Piano della Conoscenza alla Casa di Obellio Firmo', in Pompei Intra-Extra. Archeologi dell'Università di Bologna a Pompei. Archeologist from the University of Bologna at Pom- 
peii, edited by Giuseppe Sassatelli and Enrico Giogi, Bologna: Bononia University Press, 23-36.

Giuffrè Antonino 1991. Letture sulla meccanica delle murature storiche. Roma: Edizioni Kappa.

Guidolbaldi Maria Paolo and Fabrizio Pesando. 2016. Pompei, Oplontis, Ercolano, Stabiae. Le tecniche edilizie, Roma-Bari: Laterza.

Jacobs, Geoff., 2005, "Registration and Geo-referencing", in Professional Surveyor Magazine, July: 30-37.

Kastenmeier Pia, Giovanni Di Maio, Giuseppina Balassone, Maria Boni, Michael Joachimski and Nicola Mondillo. 2010. 'The source of stone building materials from the Pompeii archaeological area and its surroundings', Period. Mineral, Special Issue: $39-58$.

Lorenzoni, Sergio, Eleonora Zanettin and Anna Claudia Casella. 2001. 'La più antica cinta muraria di Pompei. Studio petro-archeometrico', in Rassegna di archeologia classica e postclassica, XVIII(B): 35-49.

Maiuri, Amedeo. 1930. 'Studi e ricerche sulle fortificazioni antiche di Pompei', Monumenti Antichi dell'Accademia dei Lincei, 34 (2), coll. 113-290.

Mandolesi A. 2017. 'All'ombra del vulcano. Echi di antiche battaglie', in Archeo 388: 12-14.

Marino, Luigi. 2016. Il restauro archeologico. Materiali per un atlante delle patologie presenti nelle aree archeologiche e negli edifici ridotti allo stato di rudere. Il rischio nelle aree archeologiche". Firenze: Altralinea.

Mastrodicasa, Sisto. 1993. Dissesti statici delle strutture edilizie: diagnosi, consolidamento, istituzioni teoriche, applicazioni pratiche, IX Milano: Hoepli.

Mazois, Charles François. 1812-1824. Les ruines de Pompéi, vol. I . Paris: Librairie de Firmin Didot Freres.

— 1824. Les ruines de Pompéi, vol. II. Paris: Librairie de Firmin Didot Freres.

- 1829. Les ruines de Pompéi, vol. III. Paris: Librairie de Firmin Didot Freres.

1838. Les ruines de Pompéi, vol. IV. Paris: Librairie de Firmin Didot Freres.

Nissen, Heinrich. 1877. Pompeianische Studien zur Städtekunde des Altertums, Leipzig.

Osanna, Massimo, 2018a. 'Pompei al tempo del Grande Progetto. 2012-2018', in Restaurando Pompei. Riflessioni a margine del Grande Progetto, edited by Massimo Osanna and Renata Picone, Roma: L'Erma di Bretschneider, 99-130.

. 2018b. "Restaurando Pompei: le ragioni di un bilancio in progress', Restaurando Pompei. Riflessioni a margine del Grande Progetto, edited by Massimo Osanna and Renata Picone, Roma: L'Erma di Bretschneider, 19-20.

2017. 'Pompeii. A great project for expanding knowledge, conservation and promotion', Pompei Intra-Extra. Archeologist from the University of Bologna at Pompeii, edited by Giuseppe Sassatelli and Enrico Giorgi. Bologna: Bononia UNiversity Press, 5-7.

Osanna, Massimo and Giovanni Nistri. 2014. 'Valorizzare e proteggere i parchi archeologici: il caso Pompei', in Un Capolavoro chiamato Italia. Racconto a più voci di 
un patrimonio da tutelare, proteggere, valorizzare, edited by Carlo Alberto Brioschi, Milano: Fondazione Enzo Hruby, 99-116.

Overbeck, Johannes and August Mau. 1884. Pompeji in seinen Gebäuden, Alterthümern und Kunstwerken, Leipzig, (ed. Roma, 1968).

Repertorio dei meccanismi di danno, delle tecniche di intervento e dei relativi costi negli edifici in muratura. 2007. Sisma Marche 1997, Decreto del Commissario Delegato per gli interventi di protezione civile n. 28 del 10 aprile 2002, Tipografia Grafiche Scarponi srl.

Rischio sismico di edifici pubblici, 'Manuale per il rilevamento della vulnerabilità sismica degli edifici. Istruzione per la compilazione della scheda di $1^{\circ}$ livello’. 2007, in Rischio sismico di edifici pubblici, Appendice n.1, Parte I: Aspetti metodologici, GNDT - Gruppo Nazionale per la Difesa dai terremoti, 1993 Roma.

Sgrenzaroli, Matteo and Giorgio Paolo Maria Vassena. 2007. Tecniche di rilevamento tridimensionale tramite laser scanner Volume 1 - Introduzione generale, Brescia: Starrylink.

Spano, Giuseppe. 1910, 'Pompei. Relazione degli Scavi Eseguiti nell'Anno 1907', in Notizie degli scavi di Antichità 7: 315-563.

Tempesta, Giacomo. 2011. 'La vulnerabilità sismica dell'edilizia storica e dei monumenti', in Costruire in laterizio, XXIV (140, marzo-aprile): 13-16.

Torraca, Giorgio. 1991. 'La vulnerabilità e durabilità delle pietre con particolare riferimento al caso dei templi di Paestum", in Etude de cas de vulnérabilité du patrimoine: Paestum edited by Giuliana Tocco Sciarelli. Rixensart: PACT Belgium, 157-168.

Torraca, Giorgio, Massimo Leoni, Costantino Meucci, Mariagrazia Zappalà Plossi, Marisa Tabasso Laurenzi and Marco Verità. 2002. 'Il degrado dei materiali archeologici', in Il Mondo dell 'Archeologia, 2002: 333-340.

Vallario, Antonio. and Antonio Del Gaudio. 2007. Attività estrattive: cave, recuperi, pianificazione. Napoli : Liguori Editore.

Vetter, Emil. 1953. Handbuch der italienischen Dialekte, I, Oskische Inschriften, Heidelberg: Winter. 


\section{Electronic resources}

WFD - Wave Form Digitizer Technology - White Paper

https://w3.leica-geosystems.com/downloads123/zz/tps/nova_ms50/white-tech-paper/ Leica_Nova_MS50_WFD-Wave_Form_Digitizer_Technology_TPA_en.pdf

LeicaScanStation - White paper - Tilt Compensation for Laser Scanners

http://www.leica-geosystems.co.kr/downloads123/hds/hds/general/white-tech-paper/ Leica_ScanStation_tilt_compensation_wp_en.pdf

Leica ScanStation P40/P30 - System Field Manual

https://surveyequipment.com/assets/index/download/id/735/

LeicaScanStation - White paper - HDR for Leica ScanStation P-Series

https://www.lnrglobalcom.nl/images/brochures/leica-scanstation-p-series-hdr-wp-en.pdf 